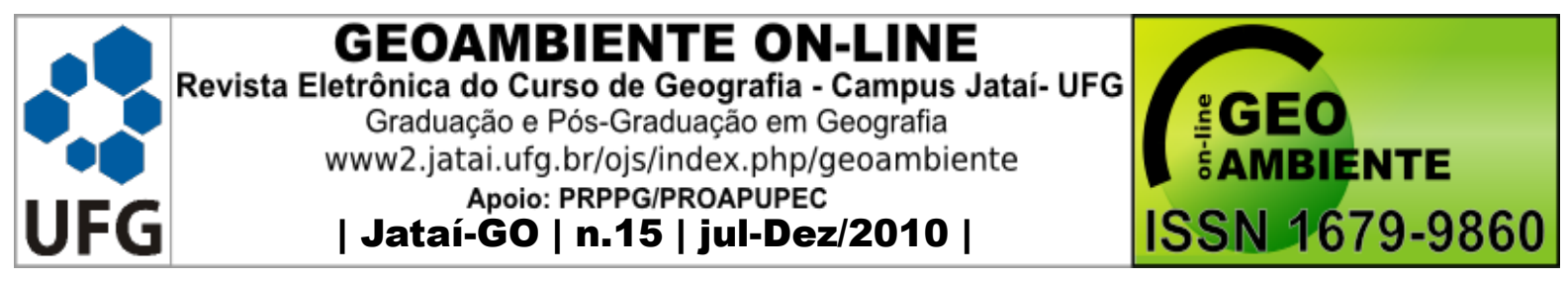

\title{
AS CONCEPÇÕES DE AMBIENTE E EDUCAÇÃO AMBIENTAL DOS PROFESSORES DE GEOGRAFIA DO ENSINO MÉDIO DO ESTADO DE GOIÁS ${ }^{1}$.
}

\author{
Valeriê Cardoso Machado ${ }^{2}$
}

(2 - Dra. em Geografia - Professora do Instituto Federal Goiano - Campus Morrinhos, geo.vale@gmail.com)

\section{Resumo}

Este trabalho tem por objetivo a análise da concepção de ambiente de professores da rede pública federal e estadual do Estado de Goiás. De acordo com a metodologia de estudo de caso e da concepção de que problema ambiental diz respeito às questões naturais e sociais, foram realizadas trinta e nove entrevistas com professores de Geografia do Ensino Médio e observado o ambiente de quarenta escolas públicas. Durante essas entrevistas, os professores foram questionados sobre a sua concepção de ambiente e educação ambiental, e a partir de suas respostas, percebeu-se, que embora as concepções sejam diferenciadas, assemelham-se sob a ótica de um discurso ainda essencialmente naturalista e tecnicista.

Palavras-chave: Ensino de Geografia - Ambiente - Concepção - Prática docente

\section{Abstract}

THE PLANNING ENVIRONMENT AND ENVIRONMENTAL EDUCATION TEACHER OF GEOGRAPHY OF SECONDARY EDUCATION GOIAS STATE .

\footnotetext{
Artigo recebido para publicação em 25 de Fevereiro de 2010

Artigo aprovado para publicação em 18 de Novembro de 2010

1 Parte deste estudo foi publicada como trabalho completo nos Anais do X Encontro Nacional de Prática de Ensino em Geografia (ENPEG) em setembro de 2009 e como resumo expandido nos Anais do VI Congresso de Ensino Pesquisa e Extensão (CONPEEX) da Universidade Federal de Goiás em outubro de 2009.
} 


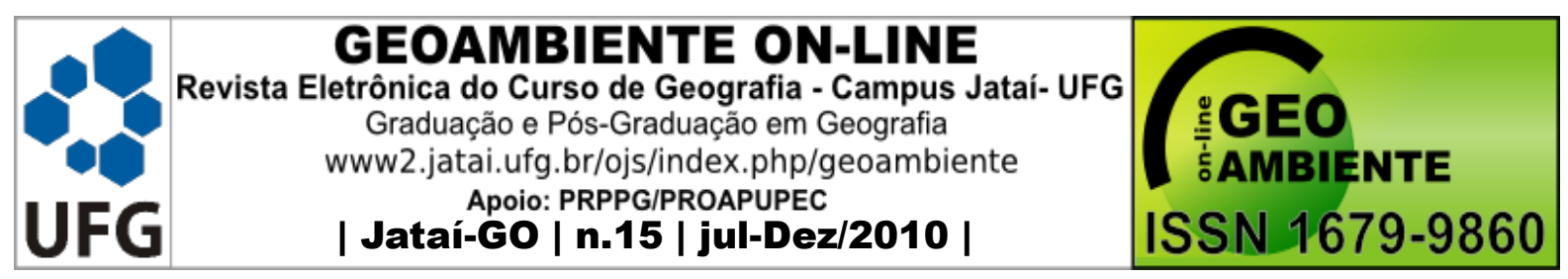

This work that hás as one of their Goias in the analysis of conception of environment of public school teachers federal and state os Goias state. According to the methodology of case study and design of environmental problem that concerns the natural and social issues, made thirty-nine interviews with geography teachers of hig scool and observed the environment of forty public schools. During these interviews we asked to teachers about their conception of environment and environmental education. From their responses it was noted that the concepts are different, however, resemble the perspective of a discourse still essentially naturalist and technicalities.

Keywords: Geography Teaching. Environment. Conception and Practice staff.

\section{Resumen}

\section{CONCEPTOS DEL MEDIO AMBIENTE Y EL MAESTRO DE EDUCACIÓN AMBIENTAL DE LA GEOGRAFÍA DE LA ESCUELA SECUNDARIA DEL ESTADO GOIÁS}

Este trabajo tiene como objetivo analizar el entorno de diseño de los maestros de escuelas públicas federales y estatales del estado de Goias De acuerdo con la metodología de estudio de caso y el diseño del problema ambiental que afecta a las cuestiones sociales y naturales, se realizaron treinta y nueve entrevistas con los profesores de secundaria de la geografía y el medio ambiente observó cuarenta escuelas públicas. Durante estas entrevistas, los profesores se les preguntó acerca de su entorno de diseño y la educación ambiental, y de sus respuestas, se observó que, aunque los conceptos son diferentes, se asemejan a la perspectiva de un discurso todavía esencialmente naturalistas y técnicos.

Palabras clave: Enseñanza de Geografía - Ambiente - Diseño - Práctica Docente

\section{1 - Introdução}

Este trabalho é uma das partes integrantes de uma tese de doutorado, da qual, dentre os seus objetivos, se destaca a análise da concepção de ambiente de professores da rede pública federal e estadual do Estado de Goiás. Para a realização da pesquisa, foram contatadas quarenta 


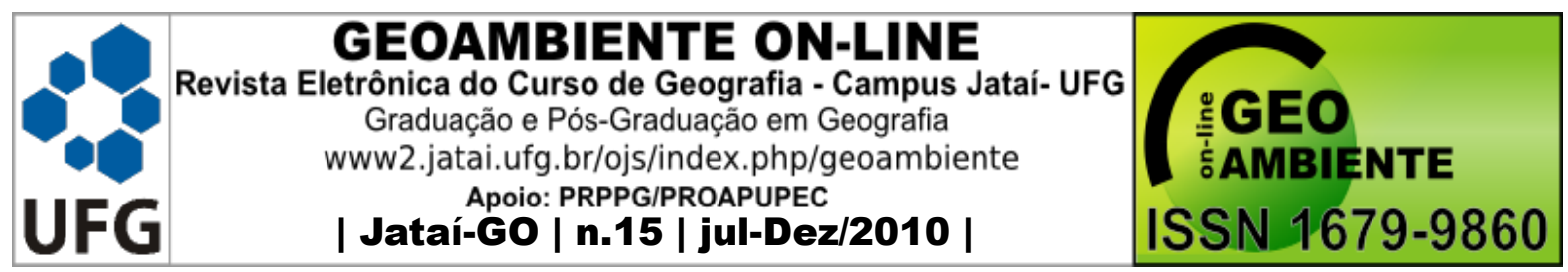

escolas, nas quais, foi realizada uma observação do ambiente, assim como entrevistas sob a perspectiva da metodologia de estudo de caso. As instituições de ensino foram selecionadas a partir da escolha de vinte municípios goianos, sendo que estes foram distribuídos equitativamente pelas cinco mesorregiões (Figura 1) do estado propostas pelo IBGE e por possuírem escolas federais e/ou duas escolas estaduais de Ensino Médio.

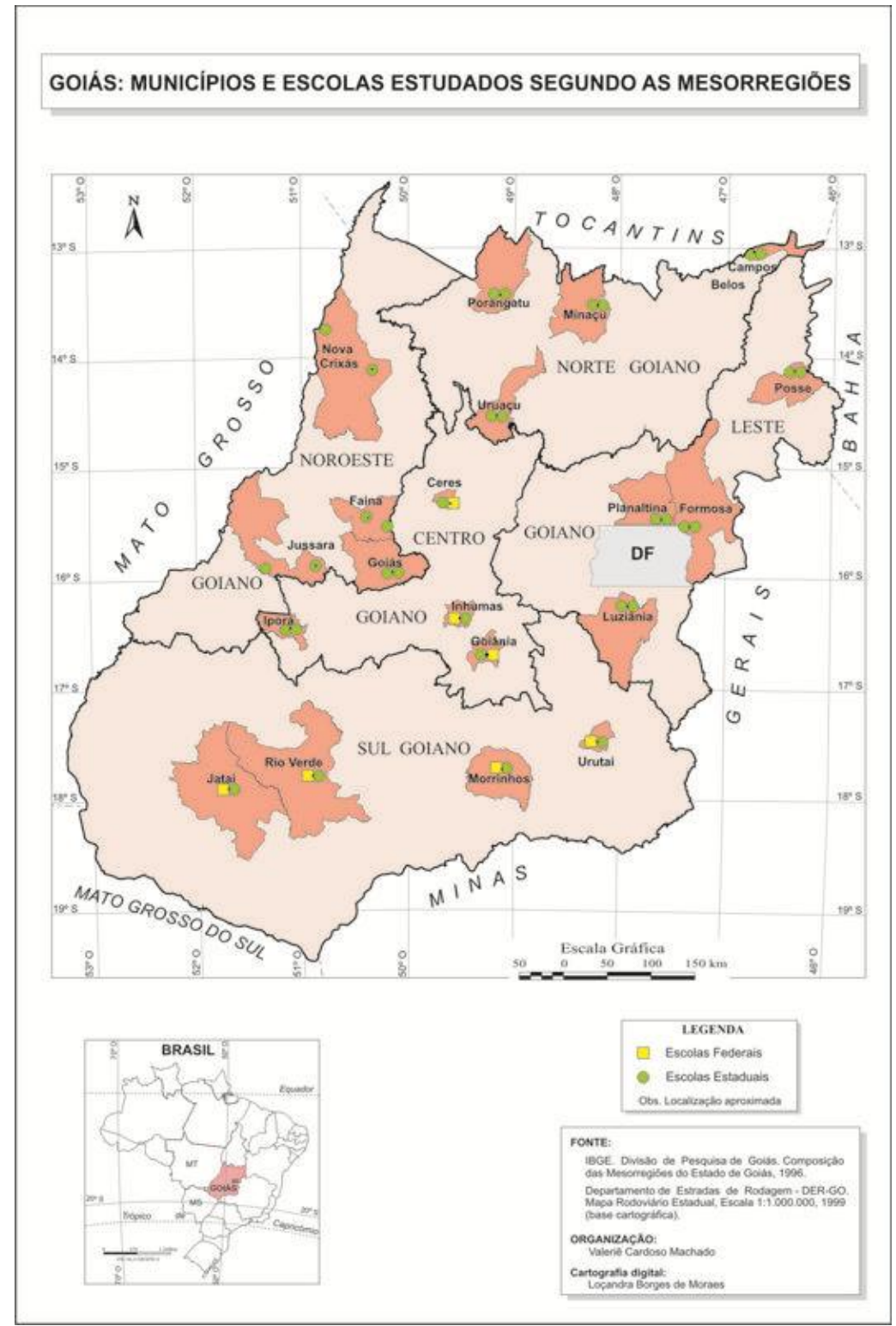

Figura 1: Mapa de mesorregiões com a localização dos município e escolas avaliadas. 


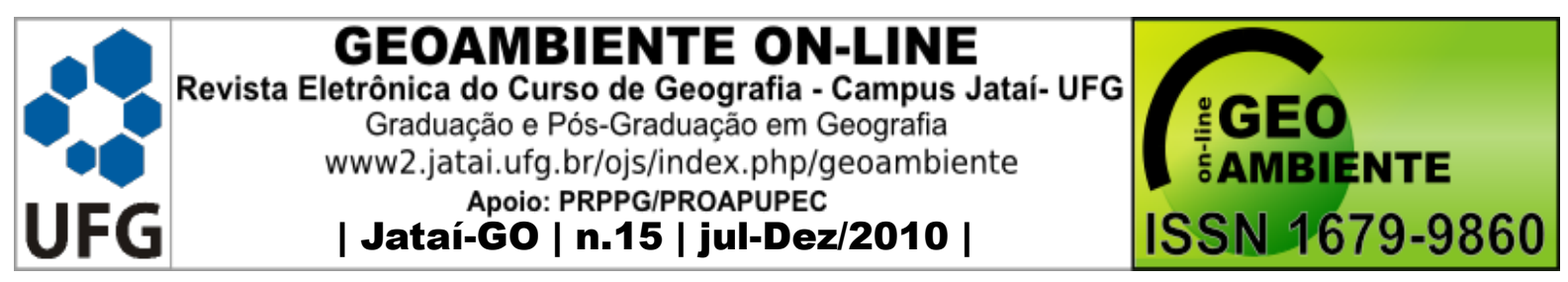

A escolha dos municípios se deu segundo critério baseado na divisão de municípios pela Secretaria de Educação do Estado de Goiás, que divide o território goiano em 38 subsecretarias regionais. Com isso, uma mesorregião pode ter várias subsecretarias, com isso, as cidades foram escolhidas, na grande maioria dos casos, por serem sedes dessas subsecretarias regionais de educação e por possuírem pelos menos duas escolas de ensino médio. Sendo assim, com base nesses critérios foram definidos os municípios da pesquisa:

As entrevistas foram realizadas com trinta e nove docentes que ministram aulas de Geografia no Ensino Médio. Na entrevista orientada, foi questionado aos professores a respeito de sua concepção de ambiente e educação ambiental. Para a realização deste procedimento foram tomados como referência os pressupostos e os conceitos norteadores de autores como Mendonça (2001, 2002), Suertegaray (2003), Loureiro (2006), Leff (2006), Rego (2002) e outros que discutem essa questão. Sendo assim, buscou-se entrevistar os docentes entendendo que ambiente é algo que aglutina o espaço e a sociedade de maneira que o homem não seja visto apenas como agente antrópico, mas sim como um integrante da paisagem e também modificador do espaço. Além disso, como parte integrante desse amplo conceito, compreendeu-se o problema ambiental não somente pelo aspecto físico como o desmatamento, mas abrangendo situações de fome, miséria e outros fatores que igualmente foram contemplados.

\section{2 - O desenvolvimento evolutivo da questão ambiental}

Ao longo dos séculos posteriores à Revolução Industrial na Inglaterra, o mundo passou a perceber o quanto o homem pode ser destruidor do meio natural, vale ressaltar que essa caracterização do homem como "destruidor" pode ter sido concebida a partir dos pensamentos de René Descartes (1596-1649), pois de acordo com Capra (1987 apud Cidade 2001, p. 109), “a natureza era vista como máquina perfeita que funciona sob as leis mecânicas e matemáticas, enquanto o objetivo da ciência era o domínio e o controle da natureza". Entretanto, muito antes de René Descartes e desse marco histórico (Revolução industrial) acontecer, o homem já poluía, degradava e destruía a natureza, um dos exemplos é a antiga Roma que possuía milhares de habitantes e não conseguiam resolver problemas sanitários, assim como outros locais do mundo 


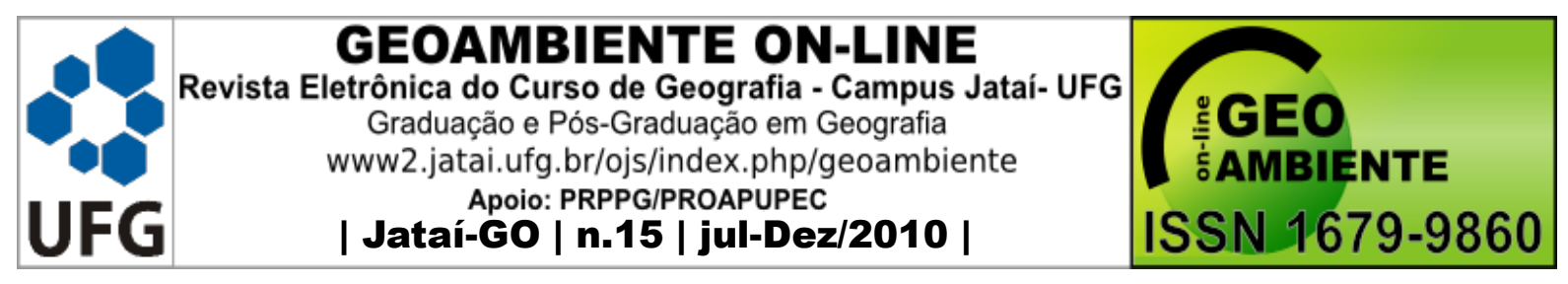

em épocas mais recentes como o caso da Índia e de muitas periferias das cidades brasileiras. Ainda no século XIX, já era forte a preocupação com a questão ambiental, tanto por parte da população como dos cientistas, de modo que motivou a criação, nos Estados Unidos, do primeiro parque nacional do mundo (MEC, 1998).

Mendonça (2002) aponta alguns acontecimentos marcantes do século XX que refletiram na economia, na política, na sociedade, na ciência e na tecnologia mundial que fizeram que a população começasse a refletir sobre o ambiente. Dentre esses, se destacam a Segunda Guerra Mundial, a Globalização e a Guerra Fria, a explosão demográfica, a seca, a fome e a desertificação na África, os movimentos sociais gerais e a abertura do conhecimento científico.

A Segunda Guerra Mundial trouxe inúmeros prejuízos a todas as instâncias sociais, entretanto, foi através de toda a destruição trazida por esse confronto que a população começou a se preocupar com as questões ambientais. Por um lado, a busca pelo desenvolvimento econômico dos países ainda em desenvolvimento e da sua continuidade pelos países desenvolvidos, no período pós-guerra, que trouxe severos danos ambientais em diversas partes do mundo, o que afetou o clima em escala global, como são notáveis hoje os problemas referentes ao efeito estufa e ao aquecimento global. Por outro lado, os países em desenvolvimento que esperavam se devolver com a industrialização trazida pelas multinacionais que tiveram de arcar com as causas do inchaço das grandes cidades - decorrido da explosão demográfica e do êxodo rural - como o desemprego, a favelização, a violência, a degradação ambiental, entre vários outros.

O único fator positivo do problema exposto foi a conscientização da população, a partir do momento que passou a perceber que os recursos terrestres são finitos em decorrência de fatores como a falta de água ou de energia elétrica, ou que o soterramento das encostas ou alagamento dos rios pode provocar grandes enchentes. Além de exemplos brasileiros como as enchentes e o deslizamento de encostas de São Paulo e do Rio de Janeiro, a partir da década de 1960, o mundo começou a assistir às condições precárias em que o povo africano estava vivendo em decorrência da seca, da fome e do aumento do deserto do Saara, frutos da ganância pela extração de matérias-primas pelas multinacionais estrangeiras. 


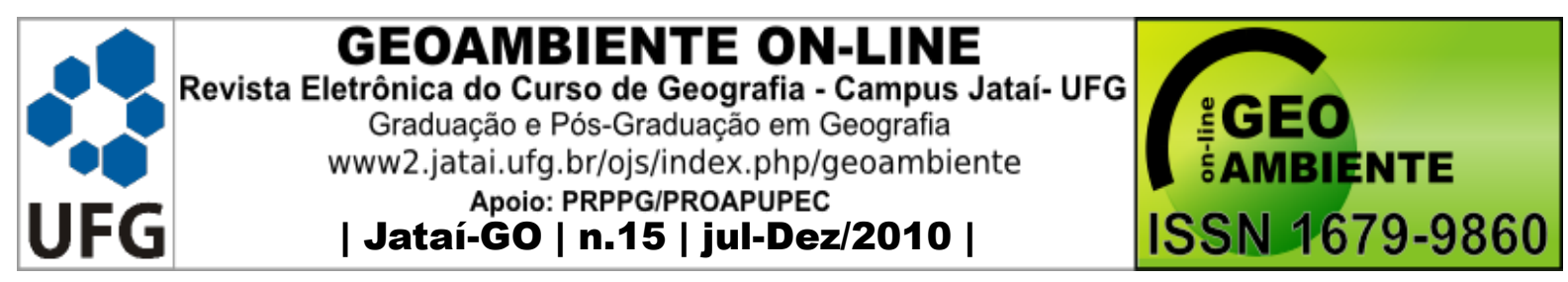

No entanto, a população não ficou somente assistindo extasiada a todas as mazelas ambientais acontecerem. A década de 1960 foi marcada por inúmeros movimentos sociais em diversas partes do planeta em prol da paz, do ambiente, da qualidade de vida e da liberdade de expressão. Um exemplo importante, sobretudo quando se trata de ambiente, foi o movimento hippie, assim como os diversos movimentos estudantis. Todas essas manifestações populacionais foram importantes para que o mundo enxergasse que certas atitudes e comportamentos precisavam mudar, assim, no que diz respeito à questão ambiental, realizou-se a Primeira Conferência Mundial do Desenvolvimento e Meio Ambiente, em 1972, em Estocolmo (com organização da ONU - Organização das Nações Unidas - e participação de diversos países) e vinte anos depois, a segunda conferência foi realizada no Rio de Janeiro, em 1992. Nessa mesma época, o Brasil criou a Secretaria Especial de Meio Ambiente (SEMA), que segundo Braga (1998), foi um ato quase simbólico devido à Conferência de Estocolmo, porque, por mais de uma década essa instituição ficou em segundo plano frente à importância de outras ações governamentais.

Ao longo das décadas de 1970 e 1980, outras conferências foram realizadas em diversas partes do mundo, inclusive na extinta União Soviética - o que demonstra que o capitalismo não é o único fator que causa destruição à natureza - país este, que teve importante contribuição para a educação ambiental ao realizar em 1977, a Conferência de Tbilisi, quando os princípios e os objetivos da educação ambiental foram criados, dos quais, muitos desses, são seguidos até os dias de hoje. No entanto, as discussões ficavam soltas, sem uma aplicabilidade direta para tentar solucionar os problemas, fato este, que ao longo das décadas, não contribuiu com a diminuição da degradação, pelo contrário, somente devido aos acontecimentos catastróficos, como o vazamento da indústria química na Índia em 1984 e a explosão do reator nuclear em Chernobyl em 1986, fez com que o mundo refletisse verdadeiramente sobre os problemas ambientais (MEC, 1998).

No Brasil, de acordo com Loureiro (2006), em 1987 o Conselho Federal de Educação definiu que a educação ambiental teria caráter interdisciplinar, contribuindo para as concepções da promulgação da Constituição Federal de 1988, a qual, retratando o contexto histórico da época 


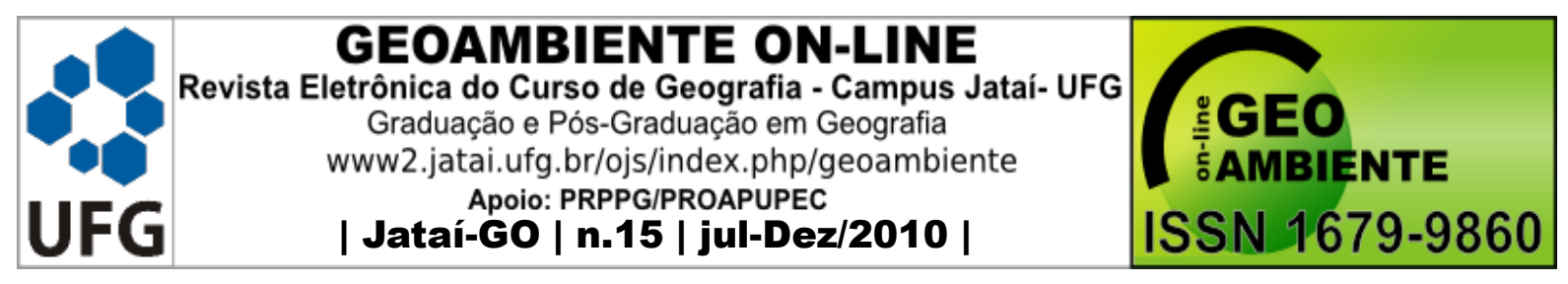

visando transformar a educação ambiental obrigatória em todos os níveis de ensino e anos mais tarde, transformá-la em tema transversal nos parâmetros curriculares nacionais (PCN's).

Além dessas questões, de acordo com Braga (1998), no início da década de 1980, o Brasil criou o Sistema Nacional de Meio Ambiente (SISNAMA) e o Conselho Nacional de Meio Ambiente (CONAMA) e instituiu a Política Nacional do Meio Ambiente (DIAS, 1993). Já no início da década de 1990, sediou um dos maiores eventos sobre a temática ambiental do mundo, a ECO-92 (Conferência das Nações Unidas sobre o Meio Ambiente). A partir dessa conferência foram elaborados diversos documentos como a Agenda 21 e foram realizadas várias discussões a respeito da educação ambiental, que permanecia como modelo tecnicista sem que houvesse realmente uma fundamentação teórica e prática, o que ressalta o caráter secundário da educação ambiental em âmbito público (LOUREIRO, 2006). A partir da discussão realizada nessa conferência foi possível chegar a conclusões importantes, dentre as quais se destaca a determinação de que as causas básicas da crise ambiental são a pobreza e o mau uso da riqueza (BRAGA, 1998).

Depois da Eco-92, outras discussões em reuniões e conferências mundiais foram realizadas como a Rio+10 (Cúpula Mundial sobre o Desenvolvimento Sustentável), em 2002. A conclusão que os próprios governantes chegaram por meio dessas discussões foi que o interesse econômico vem em primeiro lugar, mas que, é preciso agir, pois o aquecimento global, a cada ano, adquire proporções mais graves. De acordo com Oliveira e Machado (2004, p. 147), as definições e conclusões da Rio+10 são praticamente as mesmas da Eco-92, ou seja, "erradicação da pobreza, padrões insustentáveis de produção e consumo, manejo sustentável de recursos naturais e compatibilização entre globalização/desenvolvimento sustentável”.

É notório, a partir das informações anteriores, que as discussões sobre a questão ambiental já obtiveram grandes avanços, no entanto, ainda há muito por fazer quanto à aplicabilidade das teorias criadas durante as conferências. De acordo com Casseti (2004, p. 156) "hoje, sob novas bases da sustentabilidade, são poucas as práticas políticas efetivamente implementadas. O que se observa na realidade é a existência de um discurso de defesa ambiental, com uma prática que privilegia os interesses econômicos". 


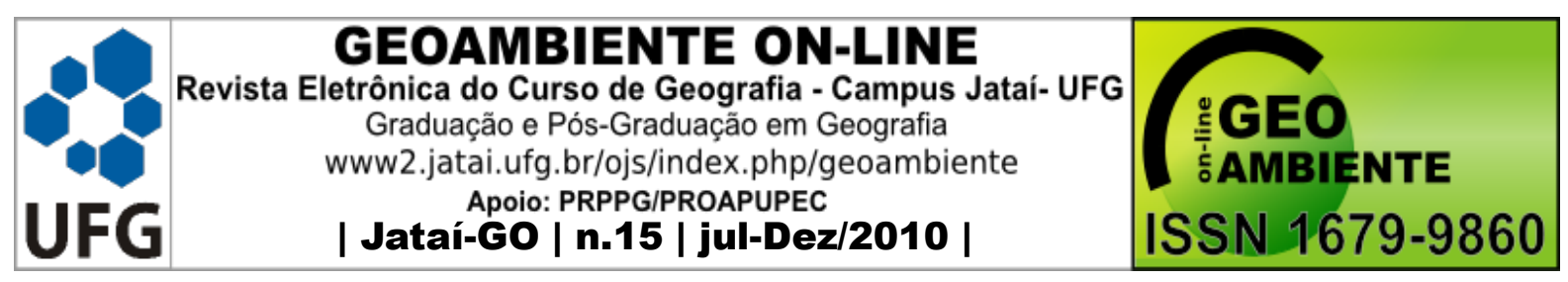

Por meio das reflexões anteriores, não se pretende aqui, induzir um pensamento naturalista e transformar o homem no exclusivo culpado da degradação do meio ambiente, nem adquirir uma postura tecnicista afirmando que o uso das tecnologias, o desenvolvimento econômico e o capitalismo são os causadores das catástrofes ambientais, tampouco assumir uma posição romântica de excessiva politização e preservacionismo radical (MORAES, 2005). Não é o objetivo e nem o foco deste estudo opinar por uma ou outra postura, ao contrário disso, acredita-se que todas são importantes para a pesquisa ambiental, pois, a junção dos fatores expostos nessas posturas alega explicitamente os reais problemas ambientais mundiais, e assim, se torna um instrumento que pode contribuir significativamente para a explicação dos desatinos dos quais o planeta tem se tornado vítima, ou seja, é possível chegar a uma conclusão mais contundente a partir da soma dos "culpados", referidos nessas concepções, que transformaram o mundo em como ele está hoje.

Apesar de ter sido dado o primeiro passo com a realização dessas conferências - de Estocolmo 1972 e da Eco-92 - o ambiente continuou a ser fortemente degradado, sobretudo, devido ao fato de os países não assinarem os tratados ou não cumprirem as deliberações e normas originadas a partir dessas conferências, como é o caso dos Estados Unidos não aceitar assinar o Acordo Internacional da Biodiversidade e mais recentemente, o Protocolo de Kyoto.

\section{3 - A Geografia e a questão ambiental}

A ciência geográfica, de forma geral, desde o seu início, estudou a questão ambiental, a natureza e os povos. No que diz respeito às novas terras descobertas, há séculos, estas sempre foram motivos de interesse e curiosidade dos estudiosos. Assim, a Geografia desde o seu surgimento, durante o seu processo de evolução até adquirir realmente o status de ciência, os seus estudos já se firmavam na relação entre homem e natureza (MENDONÇA, 2002). Dessa forma, é possível compreender que a relação entre o homem e a natureza sempre foi o objetivo da ciência geográfica, por isso, tratar de educação ambiental na Geografia não pode ser considerado como algo inovador. 


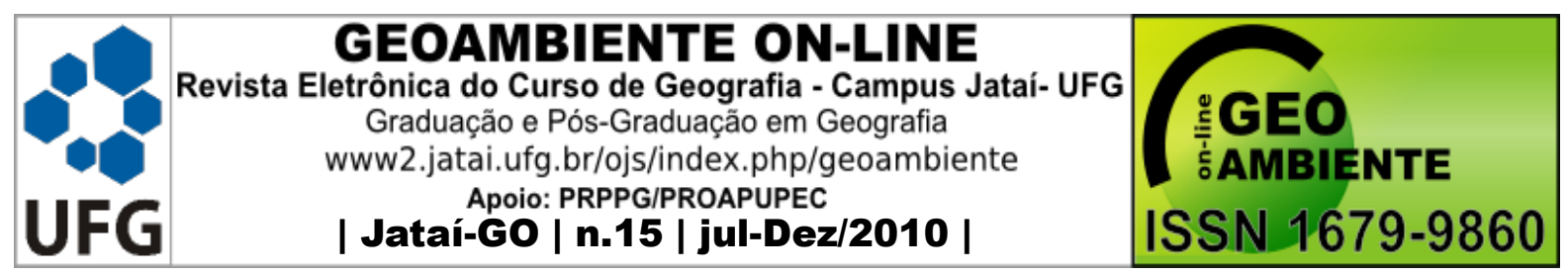

A Geografia, desde a sua origem, trata de assuntos que dizem respeito à questão ambiental, de modo que esta temática é totalmente inerente a ela. Sobre essa questão, Romancini e Martins (2005, p.101) demonstram que:

Somente a partir do século XIX foi que questões como a relação homem-natureza, a importância do meio físico no desenvolvimento social e a natureza biológica como norma e modelo passaram a constituir também o objeto de estudo das ciências humanas, pois até então era restrito ao campo filosófico.

Sendo assim, desde que a Geografia adquiriu status de ciência, no século XIX - sendo enquadrada nas ciências humanas ou outra categoria científica - a relação homem e natureza sempre fez parte de seus estudos, pois, a "geografia tem cultivado um discurso e uma prática que são tanto sociais como naturais" (CIDADE, 2001, p. 100). A autora ainda enfatiza que no decorrer do tempo, embora a Geografia sempre estudasse o físico atrelado ao humano, a ênfase desses estudos mudou,

[...] a leitura cada vez mais generalizada da questão ambiental como crise ambiental tem suscitado pressões para uma mudança de ênfase: da geografia como campo científico voltado para a compreensão de processos socioespaciais, visando à transformação da sociedade, para uma geografia como fonte de declarações prescritivas e normativas voltadas para a resolução de problemas ambientais (CIDADE, 2001, p.101)

Assim como Cidade demonstra as ênfases diferentes da Geografia em épocas diversas, Claval (2002, p.11) explica que "duas grandes concepções da geografia foram imaginadas entre o final do século XVIII e os anos de 1970. A primeira insistia nas relações entre natureza e sociedade. A segunda se preocupava com o papel do espaço no funcionamento dos grupos humanos". Mendonça em seu livro "Geografia e Meio Ambiente” (2002) faz comentários semelhantes:

[...] o meio ambiente, do ponto de vista da sociedade e da ciência, era entendido antes dos anos 50/60, como a natureza do planeta com todos os seus elementos componentes e que a geografia, assim como a biologia, a geologia e outras foram todas ciências ambientais naquele período (MENDONÇA, 2002, p. 31). 


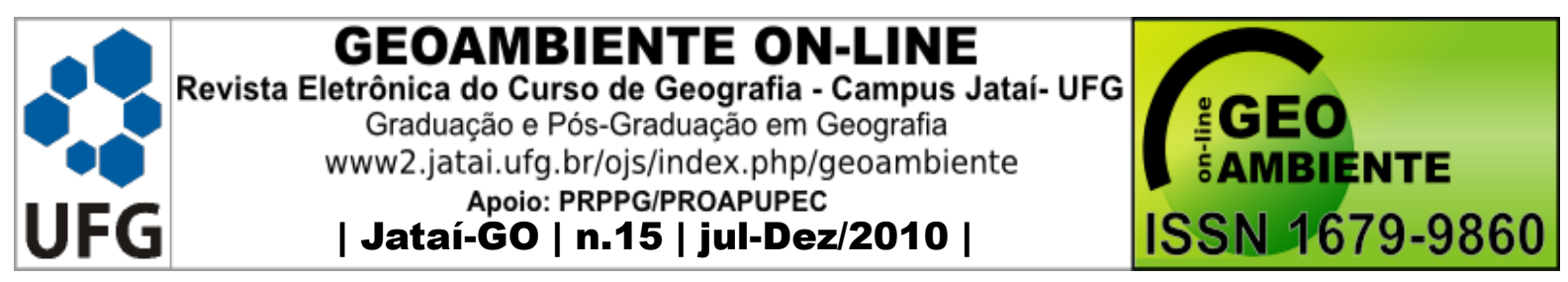

É notável, tanto nas afirmações de Cidade com nas de Claval e Mendonça que os focos dos estudos da Geografia modificaram ao longo do século, no entanto, seu objetivo principal nunca deixou de ser compreender as relações entre o homem e a natureza. Todos esses estudos foram extremamente válidos devido as suas contribuições em relação à natureza e, especialmente, pelas reflexões ecológicas contemporâneas (CLAVAL, 2002, p. 15), mas que, nem sempre é creditado o seu devido valor.

No entanto, a década de 1970 traz profundas modificações nas reflexões geográficas, pois até então, a Geografia parecia insistir na divisão entre geógrafos que estudavam a natureza, os quais pertenciam a uma tradição naturalista e os geógrafos funcionalistas que se distanciaram do enfoque físico por acreditar que o espaço "não é o produto da dinâmica da sociedade submetida às forças da natureza. É o produto de uma história" (CLAVAL, 2002, p. 20).

Essa divisão ou superficialidade dos estudos e das pesquisas, não mais satisfazia os geógrafos, fato que culminou em um período de transição durante as décadas de 1970 e 1980, o que resultou em pensamentos e reflexões advindos de uma nova corrente, de um novo paradigma com enfoque mais cultural e com ideias influenciadas pelo marxismo, a Geografia Crítica. Para Claval (2002, p. 37), o enfoque cultural "julga o mundo mais complexo", de acordo com essa nova perspectiva, o que importa não é somente o naturalismo ou o funcionalismo, mas o verdadeiro "sentido que as pessoas dão à sua existência" e que transformam os lugares.

De acordo com Mendonça (2001), a partir dos anos de 1980 até os dias de hoje, houve um significativo avanço no que diz respeito à questão ambiental, pois antes dessa data, o enfoque ecológico visava apenas à concepção naturalista, contudo, depois de 1980, a concepção de ambiente começou a ser vista, essencialmente, com base na relação entre natureza e sociedade, a qual passou a compor uma interação dialética. Foi especificamente nesse contexto histórico - e na década seguinte com o advento da Eco-92 - que a Geografia apresentou uma nova corrente, denominada por Mendonça (2001) como Geografia Socioambiental. Essa perspectiva enfatiza que os problemas ambientais enfrentados e causados pelo homem, como a fome e a pobreza, são também problemas sociais. 


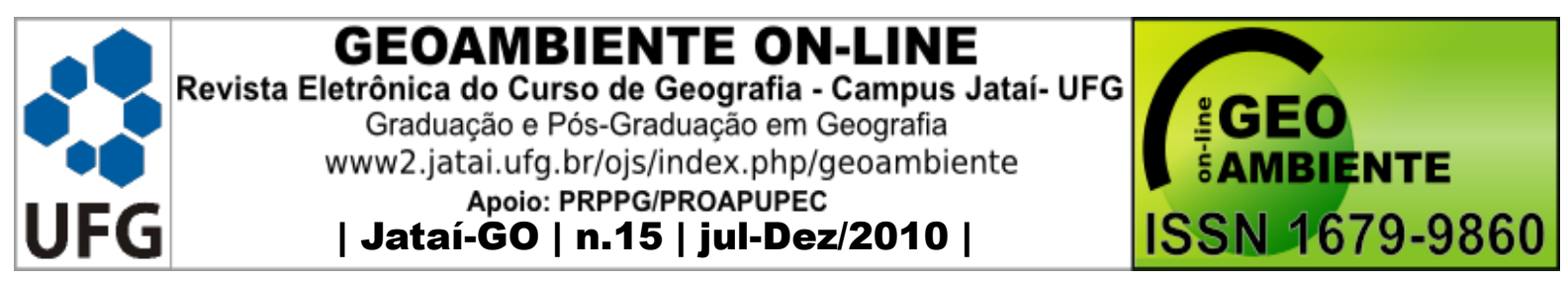

Segundo Suertegaray (2003), essa modificação no entendimento do ambiente e da questão ambiental, passa a fazer parte das discussões geográficas especialmente a partir da década de 1970, pois essa ciência sempre se colocou na interface entre natureza e sociedade. De acordo com Moreira (2002 apud SUERTEGARAY, 2003), "não mais servem os registros puros de Geografia Física diante da natureza hibridamente socializada. Também não servem os de uma Geografia Humana pura [...]", ou seja, as inovadoras discussões com enfoque na questão ambiental precisam ser mais completas, profundas e abrangentes, tratando de temas naturais interligados a temas sociais.

Apesar de a Geografia - e outras ciências - desde o seu surgimento, estudar o ambiente, Moraes (2005) considera que a questão ambiental ainda é uma temática nova, um tanto avessa aos paradigmas tradicionais, ou seja, traz uma reflexão epistemológica que permite a incorporação de novos conhecimentos, de novas técnicas, de novos paradigmas e de novas teorias.

Sobre os estudos ambientais realizados pelas Ciências Sociais, Moraes (2005, p. 82) explica que "seria interessante observar qual a viabilidade de inserções da problemática ambiental nos grandes esquemas conceituais de explicação da realidade social”, e dessa forma, reforça que "não seria possível formular uma única proposta de análise da temática ambiental para todas as ciências que estudam a sociedade, pois coexistem nesse conjunto situações diferenciadas" (MORAES, 2005, p. 83). Nessa perspectiva, no campo das ciências sociais a questão ambiental ainda é pouco desenvolvida, com exceção da Geografia (MORAES, 2005), pois, essa ciência pode servir como "uma das alavancas para o desenvolvimento da temática ambiental nas Ciências Sociais" (MORAES, 2005, p. 93). Dessa forma, para discutir as questões ambientais dentro das Ciências Sociais, é necessário compreender a relação existente entre a sociedade e a natureza, e a partir daí, os fenômenos sociais, ou seja, perceber como a sociedade se organiza e como se apropria e se submete à natureza e aos seus recursos (MORAES, 2005).

A proposta de Moraes (2005) é semelhante ao que Mendonça (2001) busca com os estudos da Geografia Socioambiental, pois para ele, com base nessas discussões, essa mais recente corrente geográfica tem uma característica multi e interdisciplinar, isso se dá porque não 


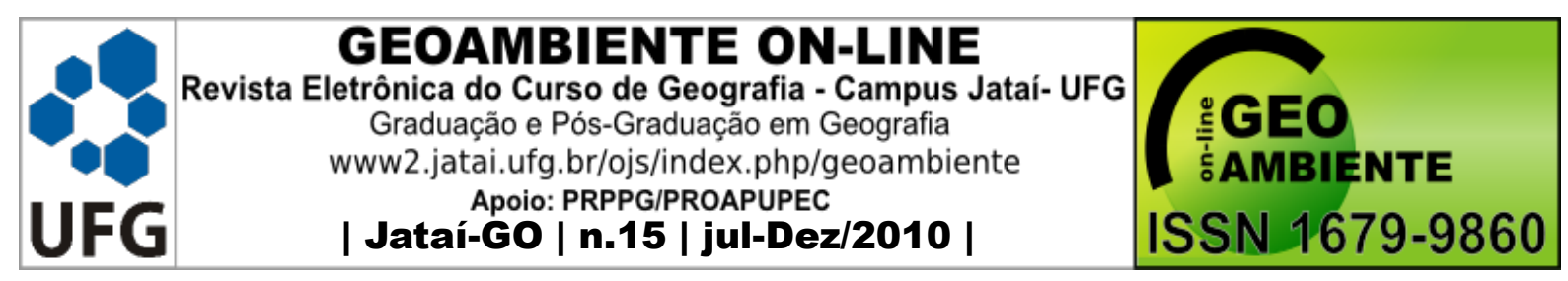

possui apenas um método e também porque o termo ambiente possui uma "pluralidade de concepções e conceitos, presentes em acepções tanto científicas, políticas e culturais [...]" (MENDONÇA, 2001, p. 118).

A Geografia com o objetivo de estudar a sociedade em relação com a natureza, concomitantemente está contribuindo para os estudos ambientais, porque o termo ambiente não abarca apenas os aspectos naturais, e sim, a relação desses com os sociais. Sendo assim, a ciência geográfica pode colaborar substancialmente para os estudos dessa temática.

Uma forma de usufruir dos estudos ambientais realizados pela Geografia é por meio da educação, ou seja, por meio do ensino de Geografia e da sua preocupação com a questão ambiental, porque atualmente essa temática está sendo propagada no mundo inteiro com o intuito de mostrar à humanidade que a qualidade de vida tende a reduzir gradativamente se a população, os políticos, os cientistas, e outros, não passarem a refletir em suas atitudes cotidianas.

\section{4 - A Geografia Escolar e a Educação Ambiental}

A Geografia Escolar, diferente da Ciência Geográfica, iniciou na Alemanha ainda não unificada, em meados do século XVIII. Posteriormente, no século XIX, a Geografia Escolar passou a ser imposta à população com intuito de promover o patriotismo (PEREIRA, 1999).

No Brasil, sabe-se que a Geografia escolar começou a compor os currículos escolares a partir de 1832, especialmente, após a criação do Colégio Pedro II no Rio de Janeiro. No entanto, foi somente no final do século XIX que a Geografia gradativamente ganhou forma na área escolar (PEZZATO, 2001; PINHEIRO, 2003). No decorrer do século XX, a Geografia Escolar no Brasil era uma forma de enaltecer o Estado e o patriotismo, assim como na Alemanha, entretanto, era bastante descritiva e decorativa, enfatizando aspectos essencialmente naturais.

Em decorrência de diversos acontecimentos históricos, em meados do século XX, a Geografia passou a privilegiar conhecimentos estatísticos e quantitativos, em favor dos ideais tecnicistas. Na década de 1960, o curso de Ciências Sociais - criado na década de 1930 - passou a substituir as disciplinas de História e Geografia, fato que fez com que essas ciências se desestabilizassem e passassem a refletir e modificar os seus paradigmas, o que culminou no 


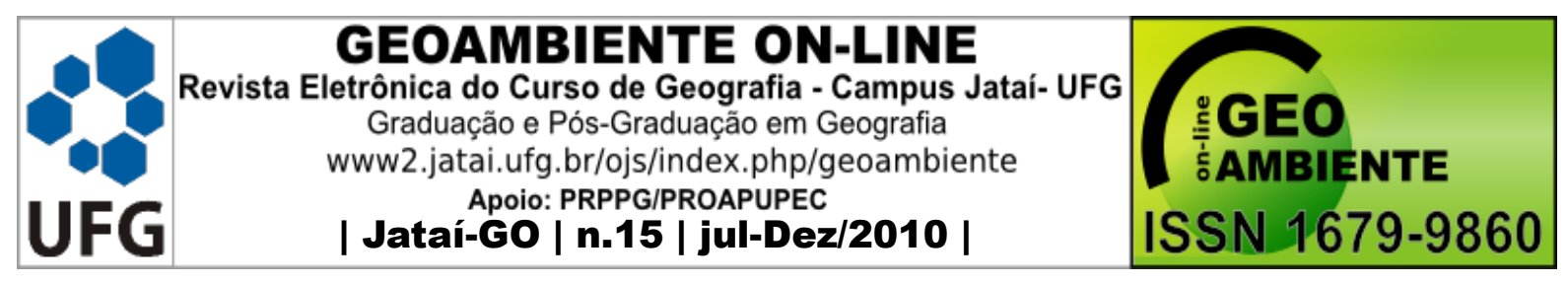

desenvolvimento da Geografia Crítica, que também deu um novo olhar para a Geografia escolar, deixando de lado as quantificações para pensar e analisar o homem e compreender as mudanças na sociedade.

Cavalcanti (2002) explica que o final da década de 1970 iniciou um período de mudanças significativas em torno de propostas de pesquisa e ensino, dessa forma, ficou conhecido como o Movimento de Renovação da Geografia. Kaercher (2007, p. 69) complementa as idéias de Cavalcanti ao afirmar que

o Congresso Nacional de Geógrafos realizado em Fortaleza em 1978 [...] é um marco de ruptura. Ali fez-se veemente crítica à Geografia tradicional e despolitizadas. (Re)iniciase mais uma vez uma longa caminhada na busca da democratização da sociedade e da escola, e, por conseguinte, da própria Geografia (sic).

A partir da década de 1990, até a atualidade, a Geografia escolar recebeu várias alterações teóricas e práticas, grande parte delas, advindas dos parâmetros curriculares nacionais e das propostas governamentais para a educação básica. Com isso, consequentemente, os objetivos do ensino de Geografia se transformaram ao longo da história até chegar a uma busca pela cidadania, pelo entendimento da espacialidade das coisas e pela possível compreensão das práticas sociais que acontecem no espaço geográfico (CAVALCANTI, 2002; SUETERGARAY, 2003).

Atualmente, as propostas de práticas de ensino em Geografia, sugerem que a disciplina trabalhe com o significado e aplicação cotidiana de conceitos geográficos como a paisagem, o território, o lugar e outros como o ambiente. No entanto, esses conceitos não devem ser trabalhados de maneira isolada, mas sim, construídos ao longo dos conteúdos geográficos de modo que propicie um possível confronto de "conceitos científicos e conceitos cotidianos" (CAVALCANTI, 2002, p. 15). Sobre a questão da criação dos conceitos e a importância deles para a compreensão dos espaços e suas relações, Cavalcanti (2002, p. 35) complementa:

[...] O conhecimento mais integrado do espaço de vivência requer hoje, mais que antes, instrumentos conceituais que tornem possível apreender o máximo dessa espacialidade; 


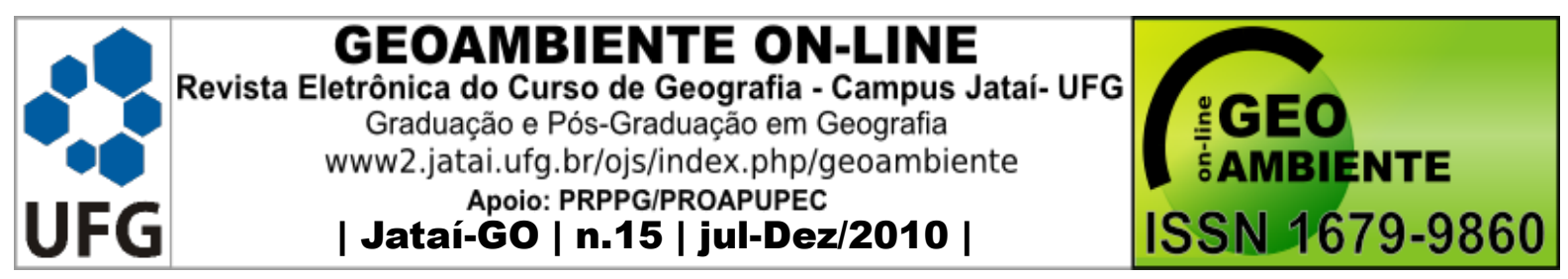

daí a preocupação com a organização dos conteúdos buscando a formação de conceitos geográficos.

Outro ponto fundamental que Cavalcanti (2002, p. 38) enfatiza é a constante utilização de mapas e outros recursos cartográficos durante diversos conteúdos da Geografia, para a autora, os recursos cartográficos fazem parte dos conteúdos procedimentais que são os que possibilitam “desenvolver habilidades e capacidades para se operar com o espaço geográfico”. Entretanto, a questão ambiental faz parte dos conteúdos atitudinais e valorativos que dizem respeito à formação de valores e mudanças de atitudes e comportamentos, o que contribui favoravelmente com a ação do aluno no espaço.

Kaercher (2007) possui uma concepção de ensino baseada nas teorias de Paulo Freire, e, dessa forma, o autor, constantemente, comenta a respeito de temas geradores e situações-limite. Relacionando os pensamentos de Kaercher com os de Cavalcanti, subentende-se que a educação ambiental e/ou a questão ambiental podem, além de pertencer aos conteúdos valorativos e atitudinais, ser um dos temas geradores para o professor de Geografia desenvolver suas aulas e pode também ser encarado como uma situação-limite, pois

a Geografia pode ser um instrumental valioso para elevarmos a criticidade de nossos alunos. Por tratar de assuntos polêmicos e políticos, a Geografia pode gerar um sem número de situações-limite, quebrando-se assim a tendência secular de nossa escola como algo tedioso e desligado do cotidiano (KAERCHER, 2007, p. 65).

O ensino de Geografia, atualmente, tem como principal objetivo preparar o aluno para ser um cidadão mais crítico, consciente e ativo na sociedade em que vive. Dessa maneira, não só o ensino de Geografia, mas também a escola deve se preocupar em transmitir a seus alunos "atitudes ético-valorativas dirigidas a valores humanos fundamentais como a justiça, a solidariedade, o reconhecimento da diferença, o respeito à vida, ao ambiente, aos lugares, à cidade" (CAVALCANTI, 2002, p. 46). Essas ideias também são entendidas e subentendidas nas obras de Suertegaray (2003), Rego (2002) assim como de Kaercher (2007, p. 57) quando esse afirma que "se a escola for um espaço de diálogo e de questionamento estaremos deixando boas 


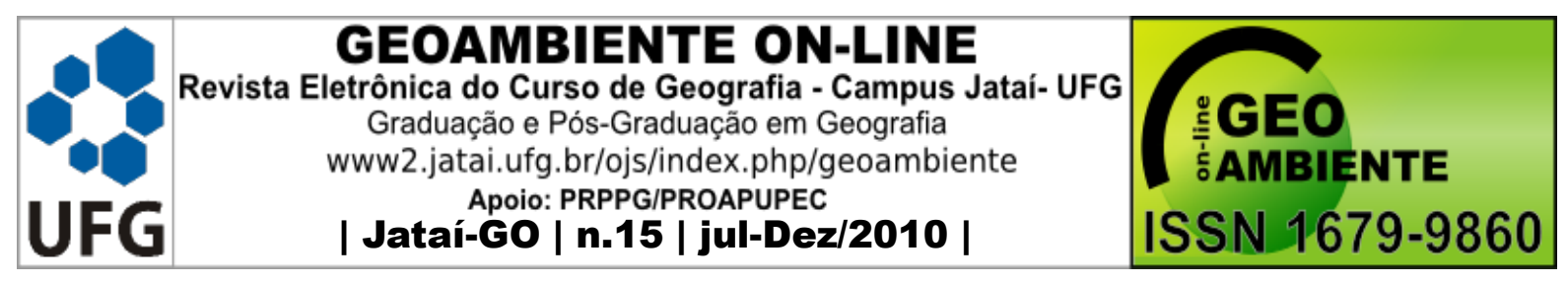

sementes para que essas qualidades - diálogo e questionamento, - se enraízem pelas demais instituições da sociedade".

\section{5 -- Geografia, Educação e Ambiente}

Como mencionado anteriormente, acredita-se que através da educação, a mudança de comportamento e de consciência pode ser alterada de maneira positiva, pensando no bem da coletividade de todas as formas possíveis, seja na tolerância, no respeito, na convivência e na afetividade, porque se o homem respeita a si mesmo assim como o outro, certamente refletirá sobre as agressões contra a natureza e entenderá que ele não está indissociável dela. Por meio desses pensamentos, compreende-se o quanto a educação pode contribuir para a melhoria da sociedade, e consequentemente, para o ambiente.

De acordo com Morin e Moigne (2000, p. 15) "a humanidade traz em si mesma os princípios de sua própria regeneração, embora adormecidos [...]" só é necessário estimular a vontade de regenerar ou de recriar que está presente na humanidade, está presente em todo lugar, em todo ser humano e em todas as sociedades. Sendo assim, como explica Morin e Moigne, acredita-se que a escola, através da educação ambiental praticada no ensino de Geografia, assim como no ensino de todas as outras disciplinas e nas próprias atitudes cotidianas da escola, pode ser um fator estimulante para as práticas de educação ambiental.

Suertegaray explica que o termo ambiente pode ser utilizado por diversas ciências, no entanto, de acordo com Leff (2001 apud SUERTEGARAY, 2003), ambiente se refere a construções históricas que tem trazido inovadoras formas de pensar a educação, buscando novas práticas emancipatórias e mais interativas, especialmente na disciplina de Geografia, que são: a valorização do conhecimento do aluno; o início do estudo geográfico a partir do lugar com o emprego de estudos do meio, objetivando a compreensão da realidade e, a partir dela, extrair diferentes temáticas; propostas metodológicas com base nos temas geradores de Paulo Freire; o revigoramento do trabalho de campo, da utilização da literatura, da música, do teatro ou do 


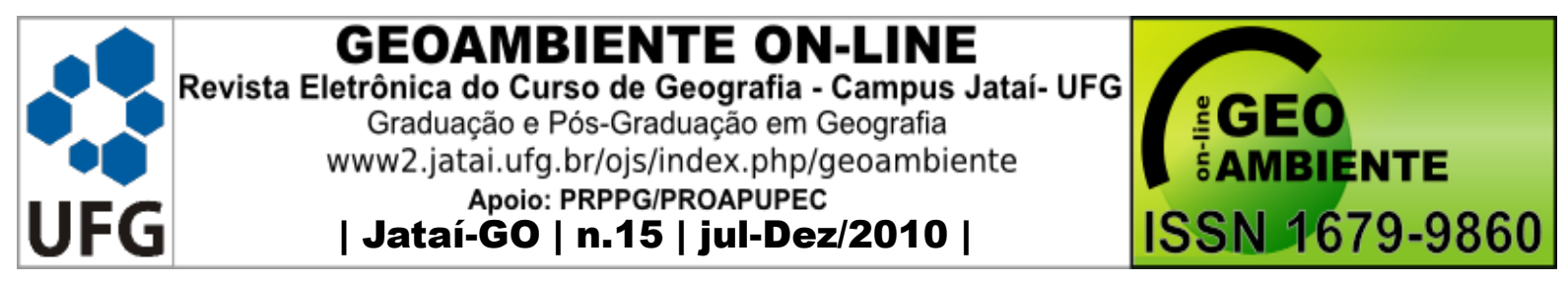

cinema; propostas que articulem natureza e sociedade, sem fragmentar as temáticas; e a construção de conceitos para a compreensão da geografia.

De acordo com Suertegaray (2003, p. 198), o principal objetivo dessas novas metodologias aplicadas ao ensino de Geografia é "fazer o aluno compreender o mundo, na medida em que se compreenda nele e, na medida em que se compreendendo torne-se sujeito", é o que Rego (2000 apud SUERTEGARAY, 2003, p. 198) denomina como construção de ambiências, ou seja, "processo de conhecimento de si e dos lugares construídos interativamente, na perspectiva de ação transformadora".

Suertegaray tenta unir educação e Geografia, através do ensino de Geografia geografando a educação. Geografar a educação consiste em promover pelo ensino da geografia uma educação para ação, indicando "a necessidade de construir com o aluno uma compreensão do lugar e do mundo e do seu lugar no mundo. Promover uma educação geradora de ambiências, ou seja, de compreensão e ação transformadora do espaço geográfico" (SUERTEGARAY, 2003, p. 200).

Para corroborar essa questão, a autora se reporta às concepções sobre educação de Edgar Morin, que explica que o caminho do saber exige a descoberta do erro e da ilusão, a superação do conhecimento fragmentado; ensinar a compreensão do que somos, ou melhor, ensinar a história e a identidade planetária; educar para enfrentar as incertezas, educar para a compreensão humana de modo que se garanta a solidariedade intelectual e moral da humanidade; educar para a ética do gênero humano, para isso, a educação deve conduzir à compreensão da complexidade e da diversidade humana, e dessa forma, promover, pela dialógica democrática, a construção da cidadania planetária (SUERTEGARAY, 2003).

Para geografar a educação, é necessária uma perspectiva de educação que inclua a construção da cidadania com base em uma ecologia da ação, ou seja, "trata-se de resgatar, enquanto possibilidade de vivência responsável, a solidariedade (com os outros), o cuidado (com os objetos) e a responsabilidade ética (com as ações)" (SUERTEGARAY, 2003, p. 203).

Diante do exposto, o estudo das concepções teóricas, até o presente momento, faz despertar curiosidades e anseios sobre a efetividade das práticas ambientais na Geografia enquanto ciência e enquanto disciplina. Dessa forma, a metodologia escolhida para o 


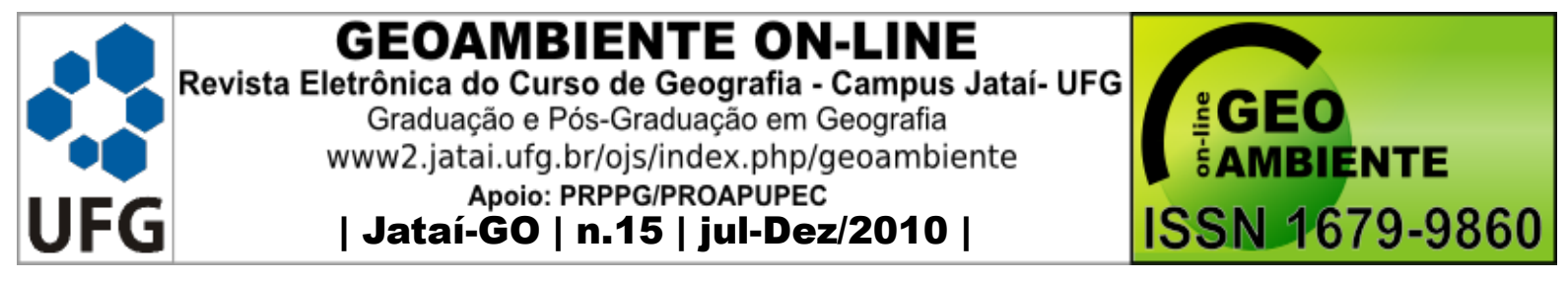

desenvolvimento deste estudo foi entrevistar professores de Geografia e visitar escolas públicas, pois, essa é uma das formas de avaliar a evolução dos estudos ambientais, sobretudo aqueles engajados à educação ambiental, na área de Geografia e de investigar a contribuição do ensino de Geografia para a educação ambiental.

\section{6 - Resultados}

Para a realização do estudo, dentre diversas atividades, foram efetuadas visitas a quarenta escolas públicas goianas e entrevistados trinta e nove docentes. No entanto, o objetivo desse artigo é ressaltar as concepções dos professores entrevistados a respeito da educação ambiental e do ambiente, e assim, perceber, de maneira sintética, como a temática da educação ambiental vem integrando as aulas de Geografia do Ensino Médio.

A partir da entrevista orientada com 392 professores da rede pública federal e estadual do Estado de Goiás foi possível adquirir uma série de informações referentes à concepção desses docentes a respeito do ensino de Geografia, da sua prática pedagógica cotidiana e das suas experiências profissionais tocantes à educação ambiental.

Percebeu-se que todos os professores entrevistados, de uma maneira ou de outra, trabalham com o tema transversal "educação ambiental" dentro da disciplina que ministram - no caso a Geografia.

O foco da pesquisa foi descobrir se os professores de Geografia têm trabalhado o tema "Educação Ambiental" nas suas aulas, ou seja, se eles têm discutido de modo transversal ou interdisciplinar na disciplina que ministra. Por esse motivo, foi questionado aos docentes se eles trabalham com essa temática disciplinarmente.

De acordo com as respostas dos professores (Figura 2), foi possível perceber que todos os docentes desenvolvem alguma atividade sobre o tema. Assim, as atividades foram agrupadas de acordo como é trabalhada a educação ambiental dentro da Geografia. 


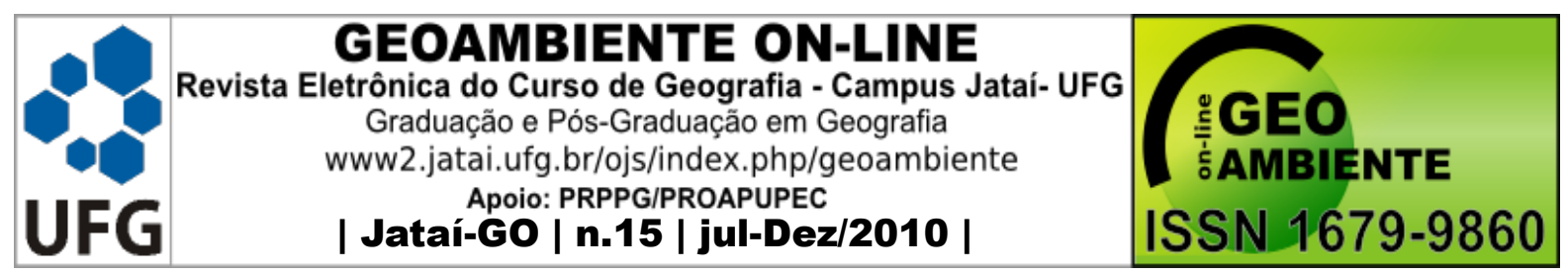

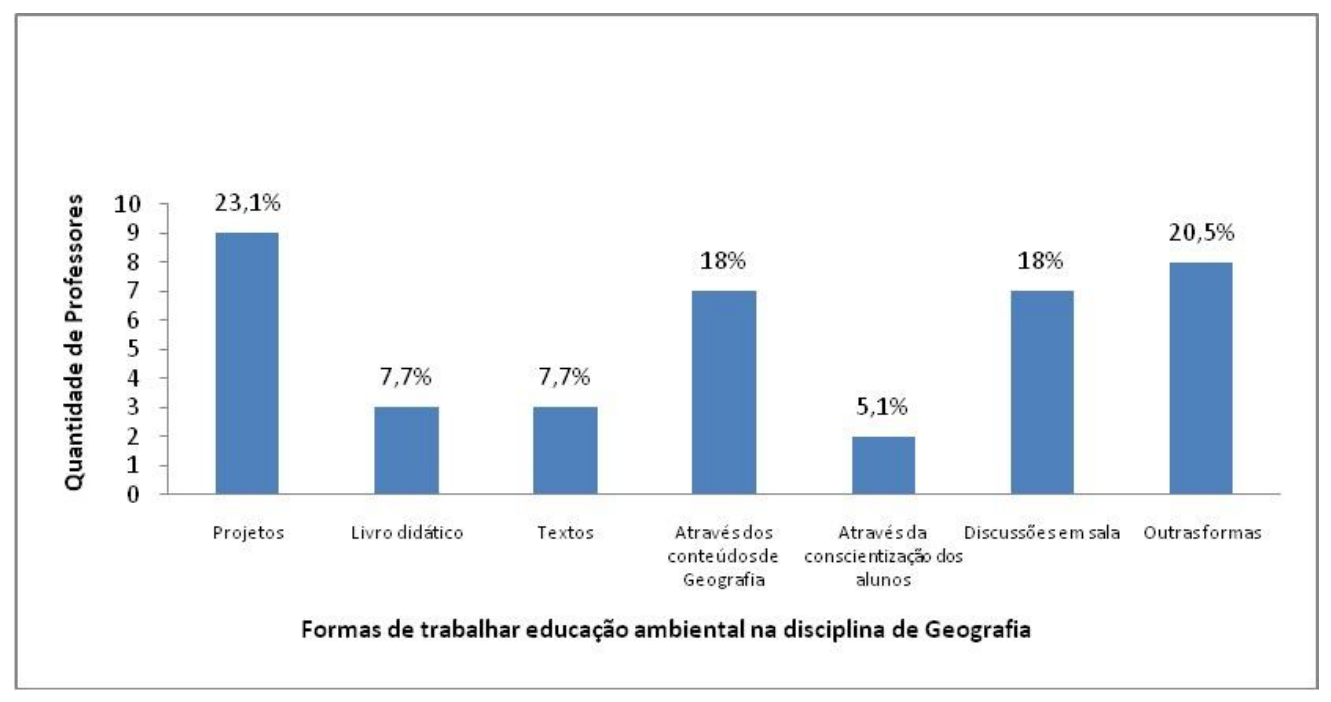

Figura 2: Forma como os docentes entrevistados trabalham Educação Ambiental dentro da Geografia nas escolas públicas goiana, 2008.

De acordo com os dados contidos no gráfico anterior, é possível observar que grande parte dos docentes trabalha essa temática por meio de projetos $(23,1 \%)$, geralmente com outros professores de outras disciplinas. Os docentes que foram enquadrados no grupo "outras formas" responderam de forma sucinta ou extensivamente, abordando várias atividades, o que as impossibilitou de serem incluídos em algum dos outros grupos.

As respostas dos professores sugerem que estes, se preocupam com a questão ambiental, pois de alguma forma, mencionam algo a esse respeito em sala. A partir daí, os professores foram questionados se consideram importante introduzir a educação ambiental dentro da Geografia. A resposta afirmativa foi unânime, ou seja, todos os professores consideram importante introduzir essa temática na disciplina de Geografia, entretanto, os motivos são diferentes, embora a maioria $(33,3 \%)$ justifique que a principal finalidade seja para conscientizar os alunos (Figura 03). 


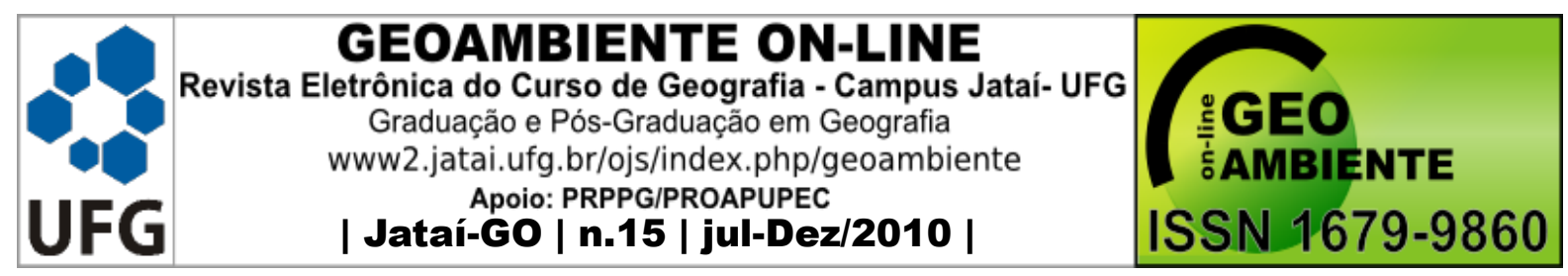

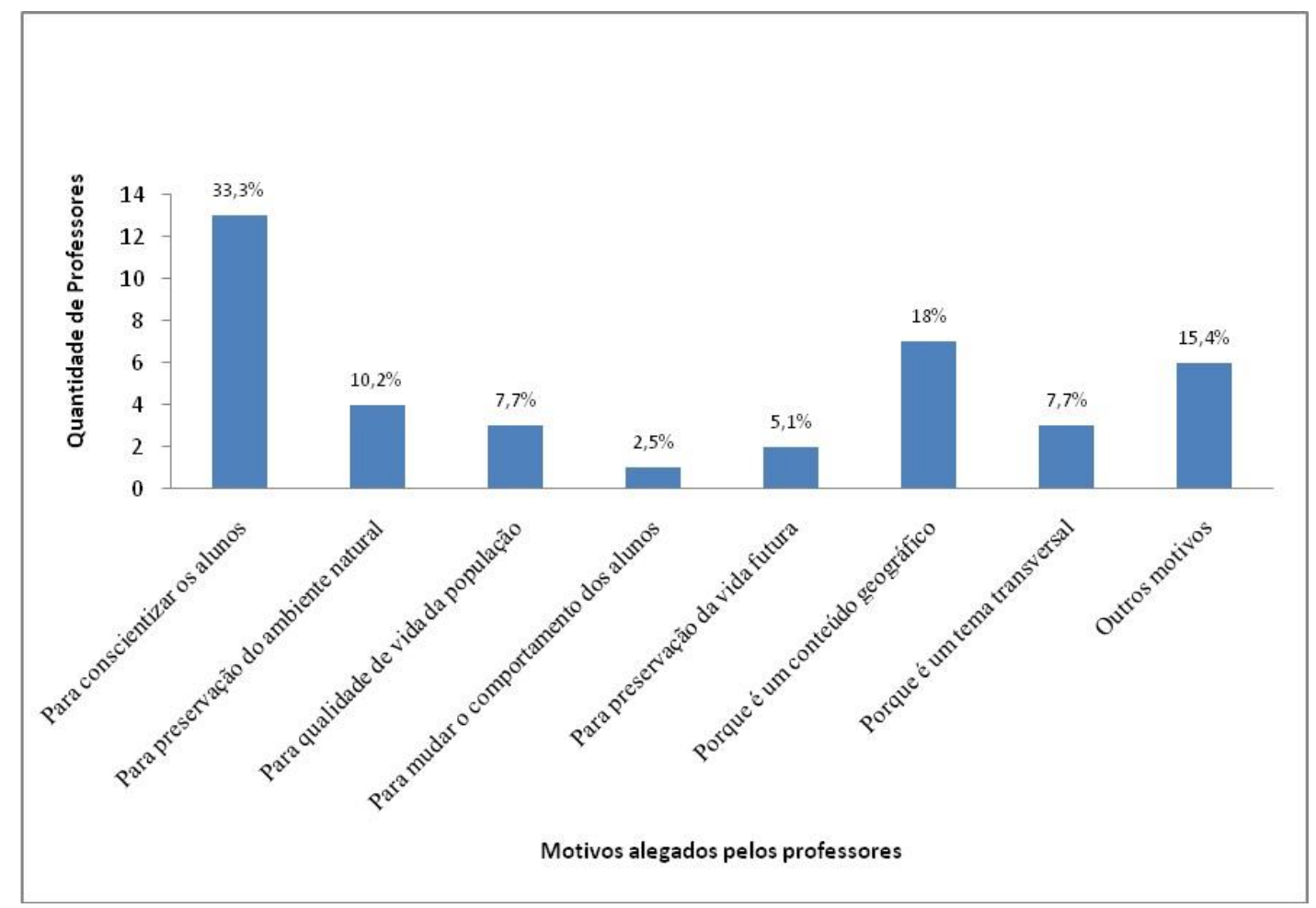

Figura 3: Motivos alegados pelos professores entrevistados para introduzir Educação Ambiental na disciplina de Geografia nas escolas públicas goianas, 2008.

Observando o gráfico anterior, percebe-se que uma quantidade expressiva - $18 \%$ dos professores - considera a educação ambiental um conteúdo da disciplina de Geografia, por interpretarem que essa matéria, por meio dos seus conteúdos, trata das questões ambientais. Sendo assim, os docentes foram questionados se havia algum conteúdo da Geografia mais indicado para trabalhar com o tema de educação ambiental.

Apesar de muitos $(28,2 \%)$ professores ainda associarem temas ambientais com conteúdos de Geografia Física (solo, relevo, vegetação, etc.), a maioria $(35,5 \%)$ dos docentes já rompeu com essa concepção e concorda que temas ambientais podem ser tratados em conteúdos da Geografia que abordam a natureza e a sociedade. É importante destacar que uma parcela significativa dos docentes $(23,1 \%)$ considera ser possível trabalhar a educação ambiental em todos os conteúdos da disciplina de Geografia. A seguir, a figura 04 demonstra a quantidade de docentes e os conteúdos geográficos que preferem para trabalhar a educação ambiental. 


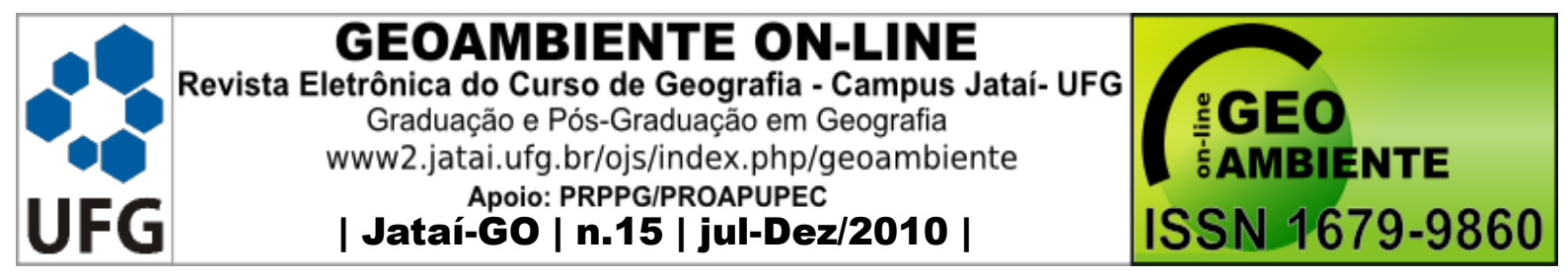

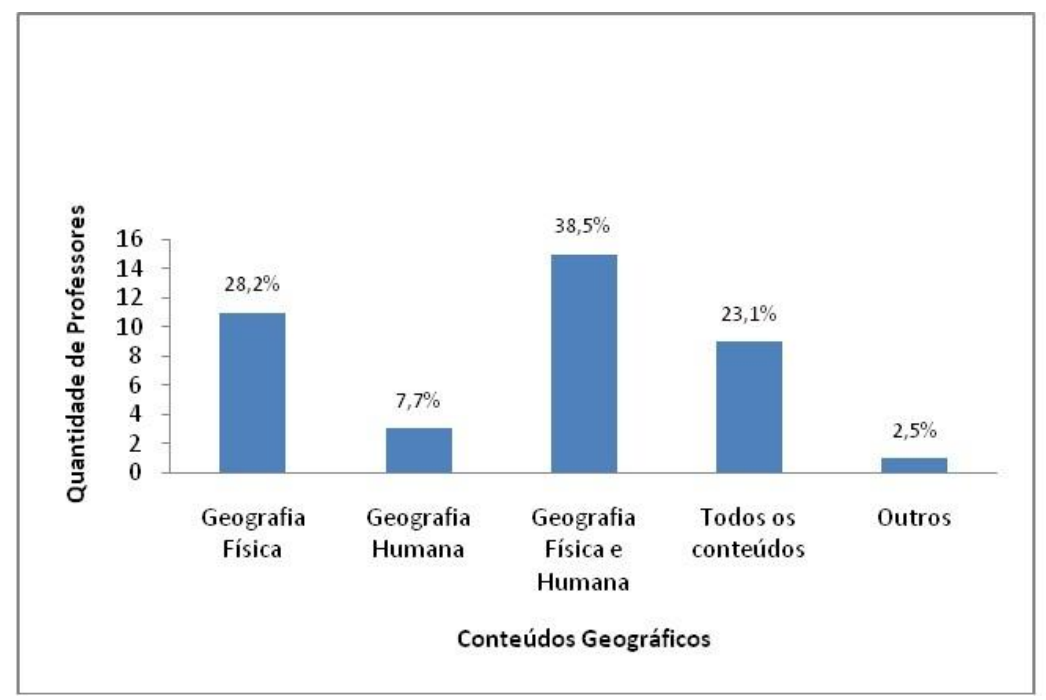

Figura 4: Conteúdos geográficos indicados pelos professores entrevistados para trabalhar Educação Ambiental nas escolas públicas goianas, 2008.

De acordo com as respostas dos professores, é possível inferir que estão trabalhando e/ou discutindo a temática da educação ambiental na disciplina de Geografia.

Como o foco da pesquisa é mostrar se os professores trabalham o tema da educação ambiental na Geografia e, como todos afirmaram que trabalham essa temática, foi perguntado a eles o que entendiam por educação ambiental. Para uma melhor visualização das respostas, as mesmas foram agrupadas de acordo com a semelhança, assim, foi possível compreender que $35,9 \%$ dos docentes entrevistados denominam a educação ambiental como conscientizar as pessoas. Por outro lado, para outros 35,9\%, educação ambiental é o mesmo que preservação da natureza (Figura 05). 


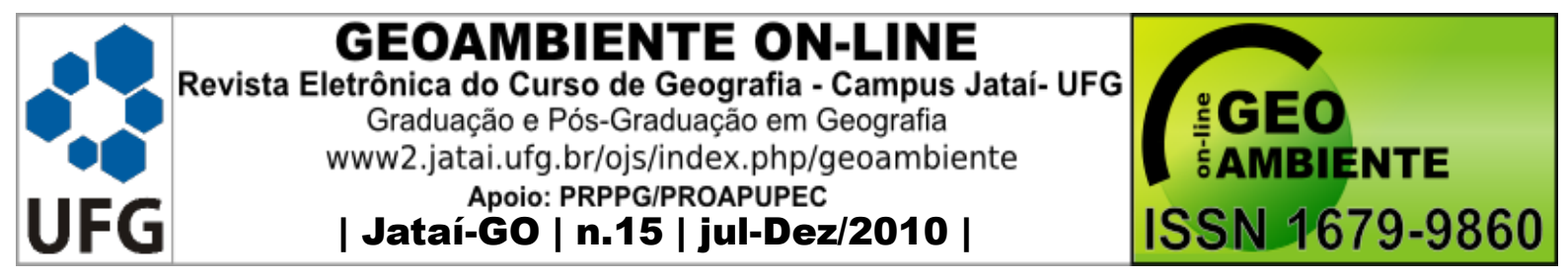

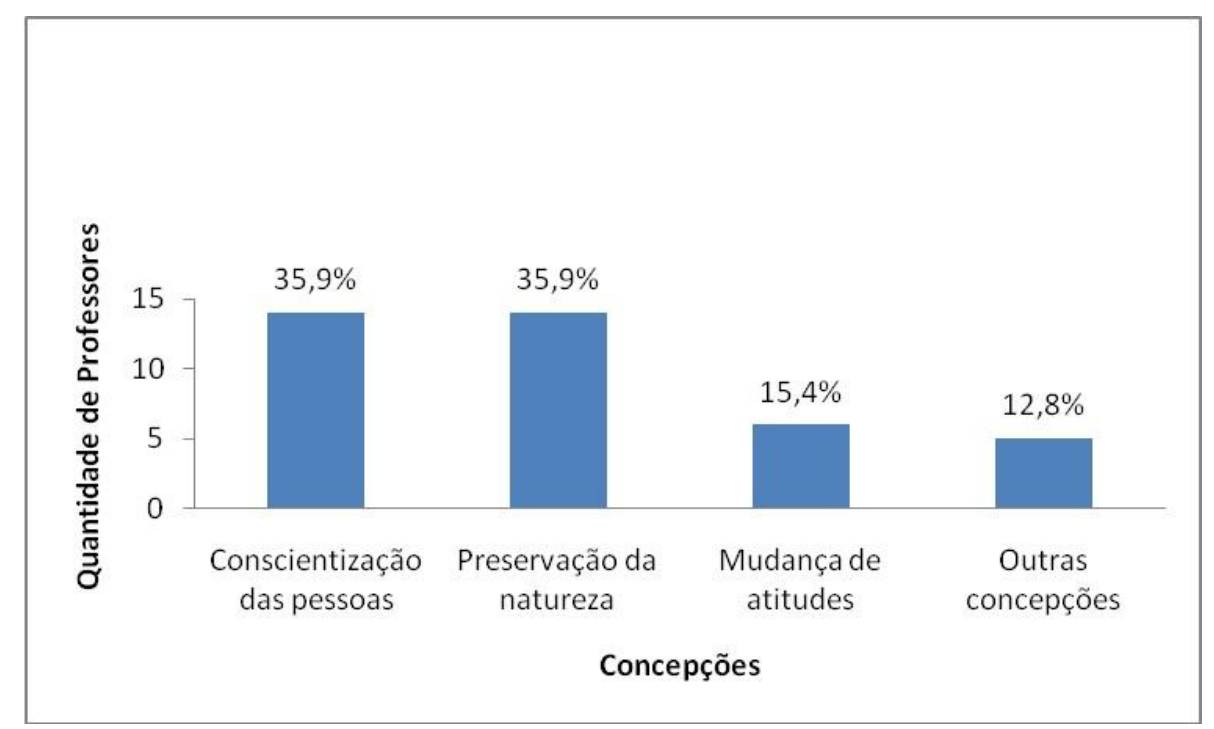

Figura 5: O que os professores entendem por educação ambiental

Durante a pesquisa, por meio das leituras bibliográficas, optou-se por utilizar a nomenclatura "ambiente” (SUERTEGARAY, 2003; SILVA E HAINARD, 2005) e evitar o termo meio ambiente por entender que este é redundante e está ligado às interpretações de natureza, ou seja, o ambiente é visto apenas pelo aspecto natural. Neste estudo, o termo ambiente é empregado para tratar do todo - das relações homem e natureza dentro de um espaço. Sendo assim, foi perguntado aos docentes o que é ambiente; a maioria (38,5\%) respondeu ser o espaço que nos cerca.

De acordo com as respostas dos docentes, para eles, o termo ambiente envolve elementos diversos, no entanto, foi possível unir algumas afirmações em oito classificações: (Figura 06). 


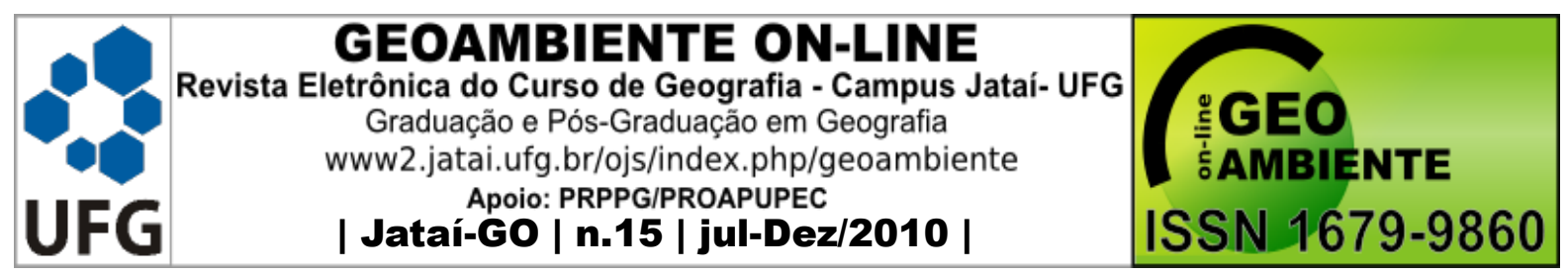

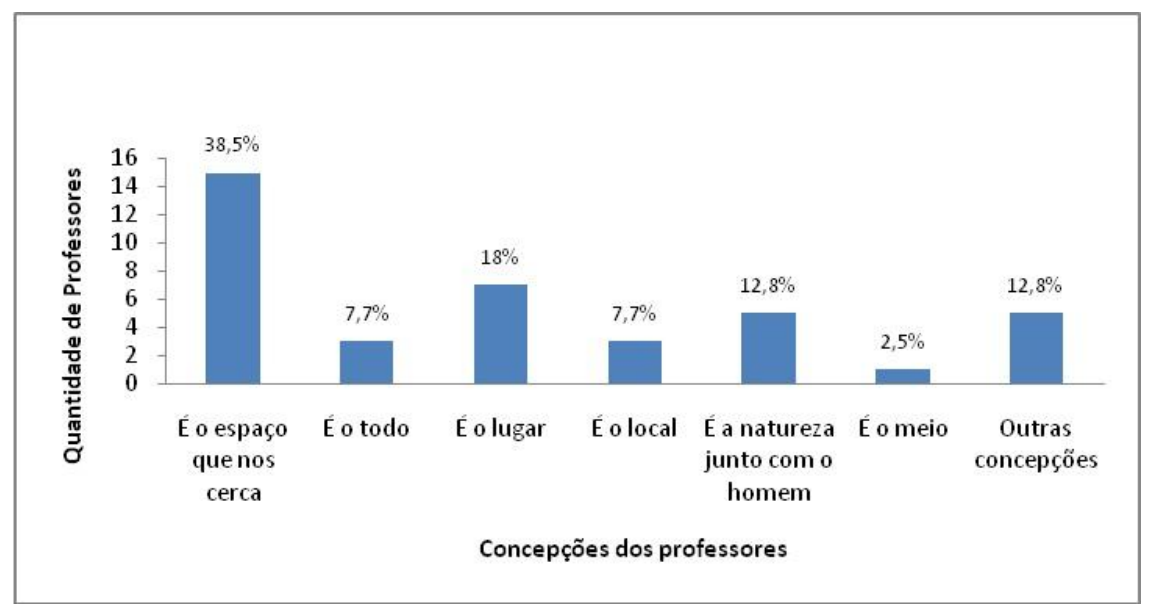

Figura 6: Concepção de ambiente dos professores entrevistados das escolas públicas goiana, 2008.

Ainda são escassas as respostas que explicam o ambiente como sendo resultado de relações entre homem e natureza. Entretanto, a maioria parece compreender que é o espaço que nos cerca, o que é um avanço frente às concepções naturalistas (MORAES, 2005). É importante destacar, observando o gráfico 05 , que $18 \%$ dos docentes entendem ambiente como sendo o lugar, ou seja, duas categorias diferentes que, na concepção deles, significam o mesmo.

De acordo com a concepção dos professores ao trabalhar a temática ambiental e apontar como sendo importante introduzi-la na disciplina de Geografia, foi questionado o que os motiva a discutir esse tema em suas aulas, se são os Parâmetros Curriculares Nacionais (PCN's), os Projetos-Políticos-Pedagógicos (PPP), as propostas da comunidade, a direção da escola, os livros didáticos, a Secretaria Estadual de Educação (SEE), os documentos oficiais como Agenda 21, ou além desses, outras motivações. Entre outras respostas, 36 professores assinalaram a opção "outras alternativas" e justificaram que se motivam especialmente pela consciência que possuem a respeito da necessidade de preservação, de cuidado com a natureza e da preocupação com a sobrevivência dos seres vivos.

Foi perguntado também quais as atividades que aqueles docentes têm costume de trabalhar para abordar a temática da educação ambiental em Geografia com os seus alunos. As atividades mais comuns (35,9\%) foram os trabalhos orais (seminários) e os escritos (pesquisas, relatórios de filmes). Com isso, percebe-se que as atividades praticadas pelos professores para 


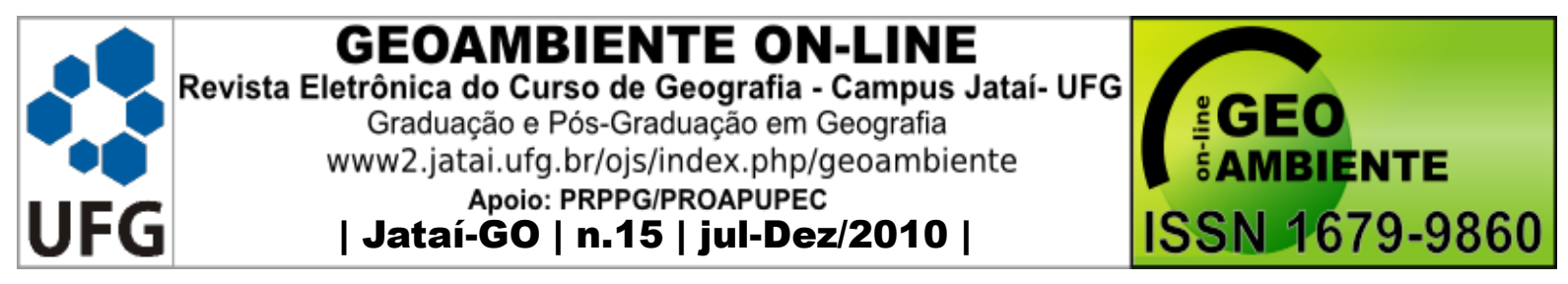

tratar da educação ambiental na Geografia são realizadas em sala de aula, geralmente por meio de filmes e/ou documentários, os quais, posteriormente, culminam com a elaboração de relatórios. Segundo eles, quando há questões em sala como perguntas de alunos ou quando os próprios conteúdos levam à curiosidade, há ocorrências de debates.

Entretanto, os docentes parecem se preocupar em mostrar imagens como fotos, figuras e mapas para que o aluno visualize os problemas e possam mudar seu comportamento. Dessa forma, foi questionado aos docentes, quais objetivos esperavam alcançar quando trabalhavam com as atividades citadas anteriormente. As respostas mais indicadas foram conscientizar os alunos e mudar o comportamento deles. A seguir, a figura 07 demonstra estatisticamente as respostas dos professores.

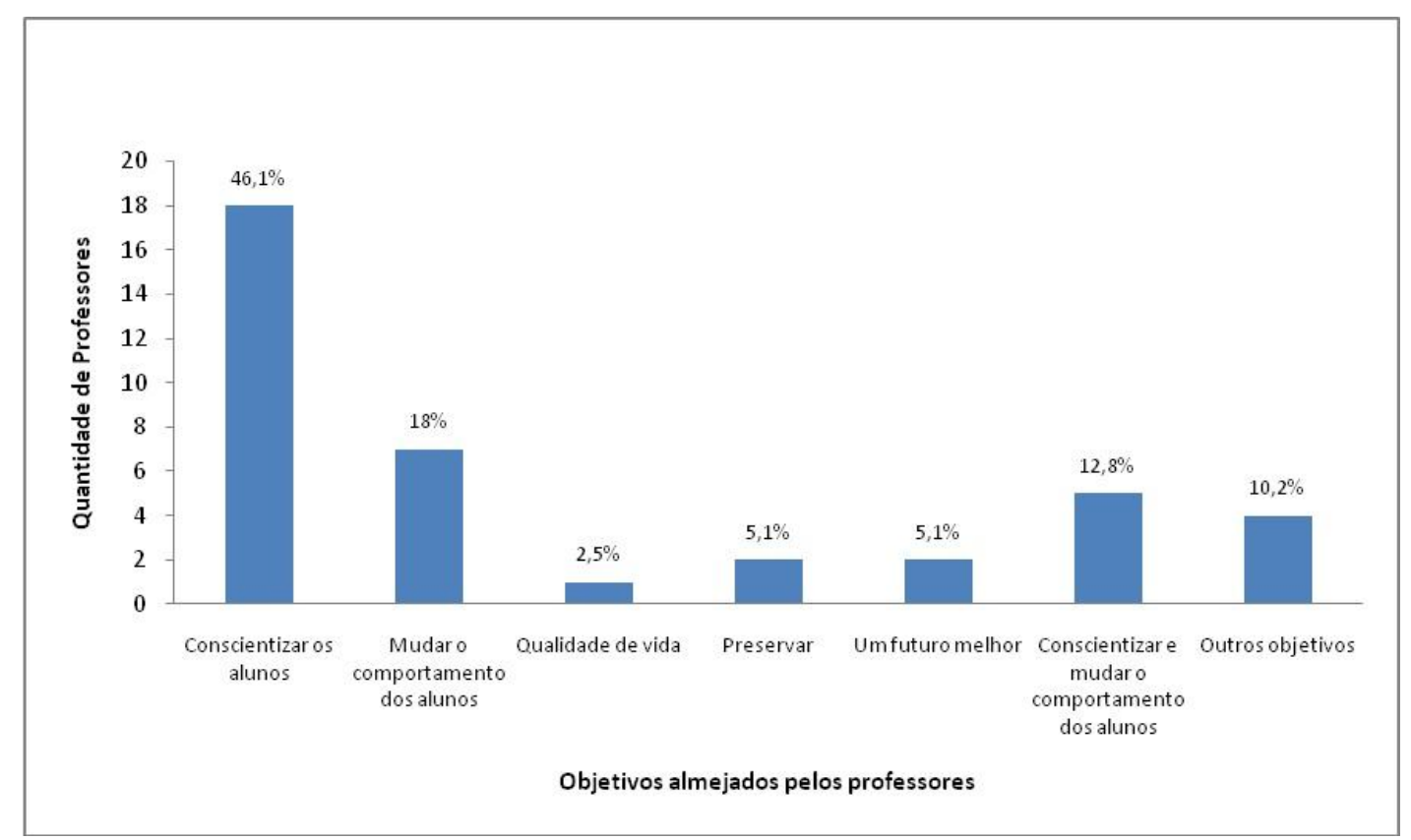

Figura 7: Objetivos almejados pelos professores entrevistados quando trabalham educação ambiental nas escolas públicas goianas, 2008.

\section{7 - Considerações Finais}

Com referência nos pressupostos teóricos deste estudo e, especialmente, baseando-se nas entrevistas com os docentes de Geografia do Ensino Médio das escolas estaduais e federais de Goiás, percebeu-se o quanto as concepções de ambiente e educação ambiental são diferenciadas, 


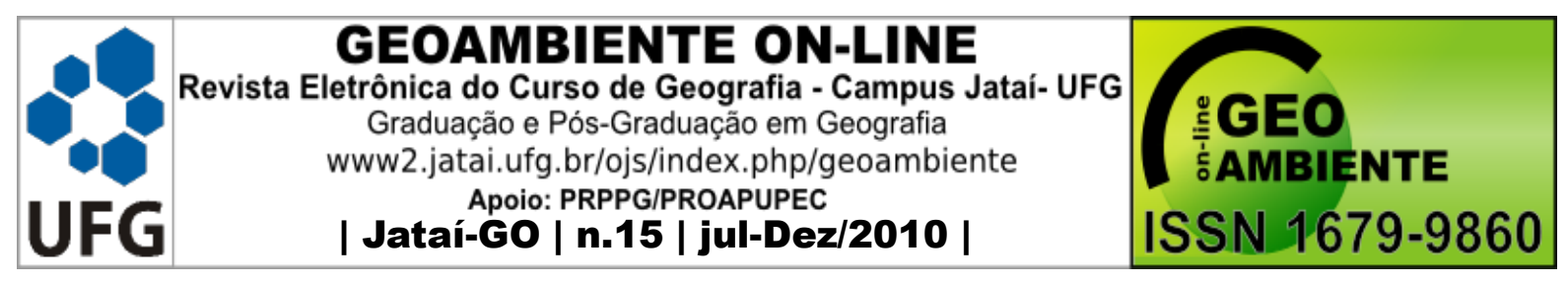

no entanto, se assemelham sob a ótica de um discurso ainda essencialmente naturalista e tecnicista.

De acordo com os dados, apesar de alguns docentes demonstrarem que seu conhecimento referente ao ambiente envolve aspectos naturais e sociais relacionado com o espaço $(38,5 \%)$ e o lugar (18\%) que os cercam, percebeu-se que na prática pedagógica cotidiana, através da descrição de suas atividades avaliativas e dos exemplos de problemas ambientais frequentes em seus municípios, o ambiente é encarado essencialmente sob a ótica dos aspectos naturais como desmatamento, queimadas, poluição de águas, lixo, entre outros, sem uma real relação desses aspectos com a questão urbana e social de suas cidades.

No entanto, é importante enfatizar os aspectos positivos que estão relacionados com a preocupação dos professores com a qualidade de vida da população atual e das próximas gerações. Assim, percebeu-se que as escolas trabalham temas ambientais direcionadas por parte de projetos, todavia, são os docentes de Geografia em sala de aula, por consciência própria, que enfatizam as questões ambientais por buscar a mudança de comportamento dos alunos e também mais consciência no que diz respeito aos problemas ambientais.

Dessa forma, conclui-se com este estudo que todos os docentes entrevistados realizam atividades pedagógicas com temáticas ambientais, sendo que a maioria dessas se caracteriza por atividades em sala e projetos $(23,1 \%)$ com o objetivo principal de conscientizar os alunos $(33,3 \%)$. Com isso, foi possível verificar que a concepção dos professores sobre educação ambiental se assemelha a estímulos e objetivos de discutir as temáticas ambientais em sala ou por meio de projetos visando à conscientização das pessoas $(35,9 \%)$ e a preservação da natureza $(35,9 \%)$. Sobre a concepção de ambiente, $18 \%$ dos professores afirmam que este termo é equivalente a lugar, por outro lado, um número maior de professores $(38,5 \%)$ afirmou ser o espaço que nos cerca e também. No entanto, esses docentes não parecem diferenciar estas duas categorias levando a uma interpretação inicial de que ambiente seria algo bastante próximo a eles.

Apesar de todos os desafios enfrentados pelos docentes e pelas escolas de forma geral no cotidiano do ano letivo, constatou-se com a realização da pesquisa que os professores entrevistados estão buscando o que recomenda Suertegaray (2003, p. 200) "construir com o aluno 


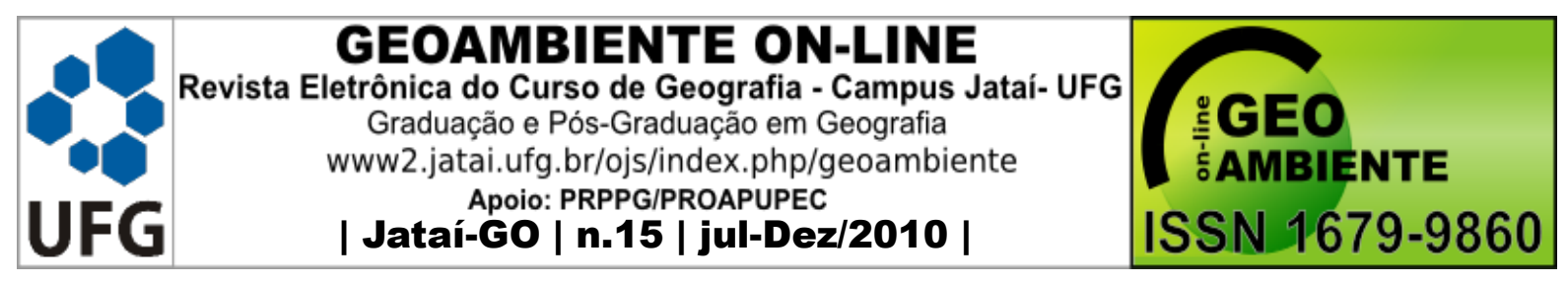

uma compreensão do lugar e do mundo e do seu lugar no mundo" promovendo uma "compreensão e ação transformadora do espaço geográfico" com uma efetiva formação de valores como tolerância, respeito, convivência e afetividade, porque se o aluno respeita a si mesmo, assim como o outro, certamente refletirá sobre as agressões contra a natureza e entenderá que ele não está dissociado dela. Assim, por meio dessa análise foi possível demonstrar o quanto a Geografia Escolar pode contribuir no trabalho sobre as temáticas ambientais.

\section{8 - Referências}

BRAGA, Maria Lúcia de Santana. As políticas desenvolvimentistas e ambientais brasileiras $e$ seus impactos na região dos cerrados. In: DUARTE, Laura Maria Goulart e BRAGA, Maria Lúcia de Santana (Org.). Tristes Cerrados: sociedade e biodiversidade. Brasília-DF: Paralelo 15, p. 93-126. 1998.

CASSETI, Valter. Impactos Ambientais em Goiás. In: GOMES, Horieste (Org.). O Espaço Goiano: abordagens geográficas. Goiânia: AGB, p.145-166. 2004.

CAVAlCANTI, Lana de Souza. Geografia e Práticas de Ensino. Goiânia: Ed. Alternativa, 2002.

CIDADE, Lúcia C. F. Visões de mundo, visões da natureza e a formação de paradigmas geográficos. In: Terra Livre. n.17. São Paulo, p. 99-118. 2001.

CLAVAL, Paul. A revolução pós-funcionalista e as concepções atuais da Geografia. In: MENDONÇA, F. e KOZEL, S. Elementos de Epistemologia da Geografia Contemporânea. Curitiba: Ed.UFPR, p. 11-41. 2002.

DIAS, Bráulio Ferreira de Souza. Conservação da natureza no cerrado brasileiro. In: PINTO, Maria Novaes (Org.). Cerrado: caracterização, ocupação e perspectivas. 2a ed. Brasília-DF: Edunb, p. 607-663. 1993.

HAINARD, François e SILVA, Marta Cassaro da. Conceitos preciosos para um trabalho interdisciplinar. In: Ambiente: uma urgência interdisciplinar. Campinas: Papirus, p.27-39. 2005. 


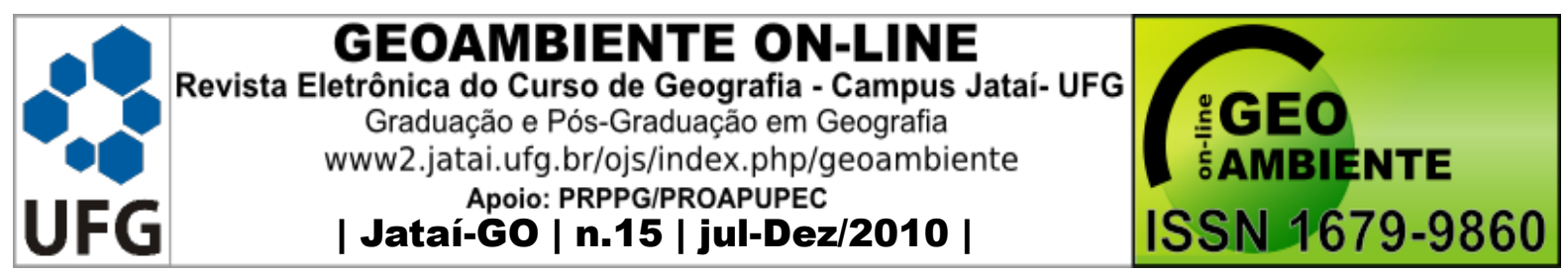

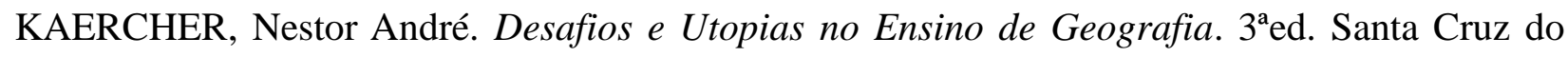
Sul: EDUNISC, 2007.

LEFF, Henrique. Epistemologia Ambiental. Tradução de Sandra Venezuela. Revisão técnica de Paulo Freire Vieira. $4^{\mathrm{a} e d . ~ S a ̃ o ~ P a u l o: ~ C o r t e z, ~} 2006$.

LOUREIRO, Carlos Frederico B. Trajetórias e fundamentos da educação ambiental. $2^{\mathrm{a}}$ ed. São Paulo: Cortez, 2006.

MENDONÇA, Francisco. Geografia socioambiental. Terra Livre, São Paulo, n.16, p.113-132, jan./jun. 2001. . Geografia e Meio Ambiente. 6aed. São Paulo: Contexto, 2002.

MINISTÉRIO DA EDUCAÇÃO E DO DESPORTO. A implantação da Educação Ambiental no Brasil. Coordenação de Educação Ambiental. Brasília-DF, 1998.

MORAES, Antônio C. R. Meio Ambiente e Ciências Humanas. 4ed.São Paulo: Annablume, 2005.

MORIN, Edgar e MOIGNE, Jean-Louis. A inteligência da complexidade. Tradução de Nurimar Maria Falci. São Paulo: Peirópolis, p.7-41. 2000.

OLIVEIRA, Lívia de e MACHADO, Lucy Marion C. P. Percepção, cognição, dimensão ambiental e desenvolvimento com sustentabilidade. In: VITTE, Antônio Carlos e GUERRA, Antônio José Teixeira (Org.). Reflexões sobre a Geografia Física no Brasil. Rio de Janeiro: Bertrand Brasil, p. 129-152. 2004.

PEREIRA, Raquel M. F. A. Da Geografia que se ensina à gênese da Geografia Moderna. 3 ed. Florianópolis: UFSC, 1999.

PEZZATO, João Pedro. Ensino de Geografia: histórias e práticas cotidianas. 302f. Tese (Doutorado) - Universidade de São Paulo. Departamento de Educação, São Paulo. 2001. 


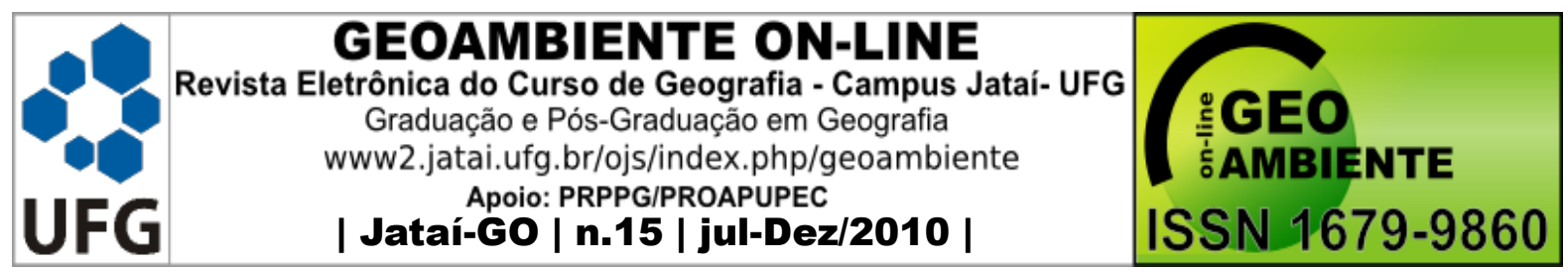

PINHEIRO, Antônio. C. Trajetória da pesquisa acadêmica sobre o ensino de Geografia no Brasil 1972-2000. 370f. Tese (Doutorado) - Instituto de Geociências da Universidade de Campinas, Campinas. 2003.

O ensino de Geografia no Brasil: Catálogo de dissertações e teses (1967-2003). Goiânia:

Ed. Vieira, 2005.

REGO, Nelson. Geração de ambiências: três conceitos articuladores. Terra Livre, São Paulo, ano 18, n.19, p.199-2002, jul./dez. 2002.

ROMANCINI, Sônia Regina e MARTINS, Eledir da Cruz. As representações da natureza no imaginário cultural da região de Cuiabá-MT. In: ALMEIDA, Maria Geralda de (Org.). Tantos Cerrados: múltiplas abordagens sobre a biodiversidade e singularidade sociocultural. Goiânia: Ed. Vieira, p. 97-114. 2005.

SUERTEGARAY, Dirce M. A. Ambiência e pensamento complexo: resignific(ação) da Geografia. In: SILVA, Aldo A. Dantas da e GALENO, Alex (Org.) Geografia Ciência do Complexus: ensaios transdisciplinares. Porto Alegre: Sulina, p.181-208. 2003. 